\title{
Receptor-Like Protein Kinases Function Upstream of MAPKs in Regulating Plant Development
}

\author{
Zhe Wang and Xiaoping Gou *(1) \\ Ministry of Education Key Laboratory of Cell Activities and Stress Adaptations, School of Life Sciences, \\ Lanzhou University, Lanzhou 730000, China; wangzh13@lzu.edu.cn \\ * Correspondence: gouxp@lzu.edu.cn
}

Received: 9 September 2020; Accepted: 12 October 2020; Published: 15 October 2020

\begin{abstract}
Mitogen-activated protein kinases (MAPKs) are a group of protein kinase broadly involved in various signal pathways in eukaryotes. In plants, MAPK cascades regulate growth, development, stress responses and immunity by perceiving signals from the upstream regulators and transmitting the phosphorylation signals to the downstream signaling components. To reveal the interactions between MAPK cascades and their upstream regulators is important for understanding the functional mechanisms of MAPKs in the life span of higher plants. Typical receptor-like protein kinases (RLKs) are plasma membrane-located to perceive endogenous or exogenous signal molecules in regulating plant growth, development and immunity. MAPK cascades bridge the extracellular signals and intracellular transcription factors in many RLK-mediated signaling pathways. This review focuses on the current findings that RLKs regulate plant development through MAPK cascades and discusses questions that are worth investigating in the near future.
\end{abstract}

Keywords: MAPKs; RLKs; signal transduction; plant development

\section{Introduction}

In plants, gene expression is strictly regulated through complex networks of signaling pathways to modulate developmental processes and responses to environmental stresses. Mitogen-activated protein kinases (MAPKs) are a group of Ser/Thr protein kinases that were originally characterized as being involved in transmitting extracellular signals into the nucleus through signaling cascades [1]. Generally, a MAPK cascade consists of three kinases, a MAPK kinase kinase (MAPKKK), a MAPK kinase (MAPKK) activated by a MAPKKK, and a MAPK (hereafter named MPK) that is phosphorylated by a MAPKK [2] (Figure 1). MAPK cascades have been found in all eukaryotes [3]. For example, the grape (Vitis vinifera) genome possesses 88 MAPK cascade genes, including 7 MAPK kinase kinase kinases (MAPKKKKs), 62 MAPKKKs, 5 MAPKKs, and 14 MPKs [4]. The Arabidopsis (Arabidopsis thaliana) genome encodes 80 MAPKKKs, 10 MAPKKs, and 20 MPKs $[5,6]$.

Plant MPKs are classified into four groups (A-D) according to the difference of the kinase structure and activation motif. The TxY motif of MPK is dually phosphorylated by dual-specificity MAPKKs. There are two kinds of TxY motif in the MPK subfamily. The MPKs with a TEY motif form three groups (A-C), and the TDY subtype is classified as a distinct group D [7]. Group A MPKs have been widely studied and found to be involved in environmental stresses, hormonal responses, and development in plants [8-12]. Group B MPKs are involved in microtubule organization, cytokinesis, and stress responses [13-15]. Tobacco (Nicotiana tabacum) NtMPK4, a group B MPK carrying an MEY instead of a TxY motif, is involved in ozone tolerance and the regulation of stomatal closure [16]. Group C MPKs have rarely been studied. It was reported that cotton (Gossypium hirsutum) MPK7 mediates defense responses against fungus and virus infection, and also promotes plant development possibly by response to phytohormone [17]. Instead of the TEY motif in groups A-C, group D MPKs have a 
TDY motif while lacking the C-terminal CD DOMAIN that is the docking site of MAPKKs [7]. Group D MPKs are involved in stress or defense responses [18]. Some findings suggest that group D MPKs mediate microtubule organization and stomatal movement [19-21].

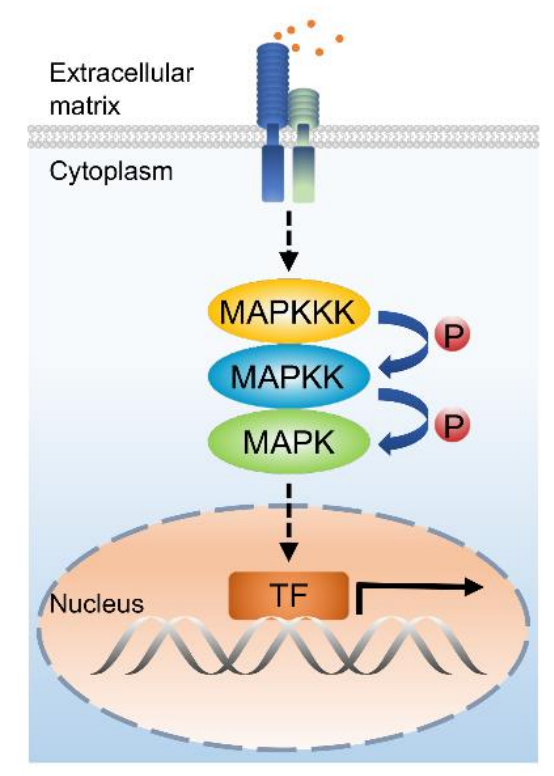

Figure 1. A general model of MAPK cascade functioning in plant development. A typical MAPK cascade contains three signaling components: a MAPK kinase kinase (MAPKKK), a MAPK kinase (MAPKK), and a MAPK. The MAPK cascade is activated by upstream regulators and transduces the signal to downstream transcription factors in the nucleus via sequential phosphorylation. The red dots represent extracellular signals that can be perceived by membrane-anchored receptors. The black arrow indicates gene expression. $\mathrm{P}$, phosphorylation relay. TF, transcription factor.

Plant MAPKKs are also called MEKs or MKKs, which are divided into four groups (A-D) according to their amino acid sequence similarity [7]. Plant MAPKKs have a highly conserved phosphorylation site $\mathrm{S} / \mathrm{T} x \mathrm{xx} x \mathrm{~S} / \mathrm{T}$ that is $\mathrm{S} / \mathrm{T} x \mathrm{xxS} / \mathrm{T}$ in human. Some group A MAPKKs regulate stress responses. For example, AtMEK1 mediates wounding-, drought-, and salt-induced signal transduction [22,23]. Inactive ZmMEK1 induces leaf senescence [24]. Group B MAPKKs have a conserved structural feature containing a nuclear transport factor 2 (NTF2) domain in the C-terminus region. AtMKK3 is a group B MAPKK, which is involved in stress response [25], immunity [26], and development [27]. AtMKK4/5 are the most thoroughly studied group C MAPKKs that are involved in many aspects of plant immunity [28,29], stress response [30], and development [31-33]. NaMEK2 regulates pollen germination and wound response in Nicotiana attenuata [34]. AtMKK7, a group D MAPKK, was reported to control plant development and stress response [35-37]. Plant MAPKKKs are classified into three groups $(\mathrm{A}-\mathrm{C})$ by homology of the kinase domain. In Arabidopsis, MAPKKKs form two main clades: MEKKs and RAF-like MAPKKKs [7]. MEKKs are typical MAPKKKs, such as YODA (YDA), MEKK1/4, and Arabidopsis NPK1-RELATED PROTEIN KINASE 1/2/3 (ANP1/2/3). These MEKKs are widely involved in development and response to environmental stresses [38-43]. Some studies have suggested that RAF-like MAPKKKs regulate defense and stress responses [28,44]. A recent study showed that RAF22 and RAF28 are necessary for the regulation of embryogenesis in Arabidopsis [45]. Sometimes, MAPK cascades have an upstream MAPKKKK, also a Ser/Thr protein kinase that may phosphorylate MAPKKKs. There are approximately 10 MAPKKKKs identified in Arabidopsis, some of which phosphorylate MAPKKs instead of MAPKKKs [46]. It was also found that some MAPKKKKs interact with MAPKKKs as scaffold proteins, and some of them are not involved in the MAPK cascades [46]. 
The first plant MAPK, MsERK1 that was identified in alfalfa (Medicago sativa), may be important in the mitogenic induction of symbiotic root nodules [47]. There has been an explosion of the research field of MAPKs in the past couple of decades, and many MAPK cascades and their functions were revealed in diverse plant species. MAPK cascades function in various processes of growth, development, immunity, and response to abiotic stress. For example, exogenous application of the elicitor peptide flagellin 22 (flg22) can activate the MEKK1-MPK4 cascade in Arabidopsis [48]. Two receptor-like protein kinases (RLKs), FLAGELLIN-SENSITIVE 2 (FLS2) and BRI1-ASSOCIATED RECEPTOR KINASE 1 (BAK1), form a receptor complex to perceive the flg22 signal and trigger the MAPK signaling cascade, thus regulating pathogen-associated molecular pattern (PAMP)-triggered immunity in Arabidopsis [49]. In addition, many reports showed that MAPK signaling regulates effector-triggered immunity (ETI) responses. An early study indicated that a fungus effector Avr9 can activate MAPKs in tobacco cells [50]. The MEK1/2-NTF6/WOUND-INDUCE PROTEIN KINASE (WIPK) cascade is involved in pathogen effector protein AvrPto-triggered disease resistance in tomato (Solanum lycopersicum) [51]. MAPK cascades are also involved in responses to abiotic stresses, such as cold, salt, and osmotic stresses. For instance, the MKK2-mediated signaling pathway is necessary for response to cold and salt stresses in Arabidopsis [52]. As one type of the most important signal transduction pathways, MAPK cascades participate in many aspects of plant growth and development. For example, in Arabidopsis, the MKK4/5-MPK3/6 cascade regulates embryogenesis, organ abscission, stomatal patterning, and lateral root emergence [41,53-56].

Consistent with their extensive functions, expression pattern analyses revealed that MAPKs are widely expressed in many plant tissues and organs, such as inflorescences, anthers, embryos, shoot and root apical meristems, root hairs and stomata [10,19,31,57,58]. Although most of them are ubiquitously expressed, some MAPKs are tissue- or organ-specific. For example, Arabidopsis MPK6 is mainly expressed in inflorescences, stomata, pollen tubes, and root meristems $[31,57,59,60]$. It was a matter of controversy whether MAPKs are nucleus-localized because of their functions in transmitting extracellular signals into the nucleus. Many studies indicated that MAPKs are localized in the nucleus [61-63]. However, some reports showed that MAPKs entered the nucleus only when induced [64,65]. MAPKs were also found to be localized on the plasma membrane [66], suggesting that they may transduce signals mediated by some membrane proteins. Some MAPK modules are localized in the cytoplasm, including the cytoskeleton and the endomembrane system. For example, AtMPK18 interacts with ALPHA-GLUCAN PHOSPHORYLASE 1 (PHS1) which localizes in the cytoplasm to regulate microtubule organization [20]. Cytoskeletal protein MAP65-1 is a target of AtMPK4, which is also involved in microtubule organization [67].

Therefore, the MAPK pathways may integrate a variety of signals from different upstream regulators, including RLKs, phytohormones, cyclin-dependent kinases (CDKs), and other signal molecules. Some studies revealed the mechanisms of crosstalk between MAPK cascades and phytohormones, such as abscisic acid, auxin, brassinosteroids, jasmonic acid, salicylic acid, and ethylene [68-71]. There were also reports about other signaling pathways that can activate MAPK cascades. For example, calcium and nitric oxide signals can regulate plant physiological processes through the MAPK signaling pathways [72,73].

Receptor protein kinases (RPKs) are important mediators that regulate cell signaling pathways in metazoans [74]. This kind of proteins perceive upstream signals and transduce them to downstream signaling pathways, such as the MAPK cascades [75]. The first plant RLK was identified in maize (Zea mays) [76]. Then, RLKs were found in other plants, including Arabidopsis and Brassica [77,78]. More than 610 RLKs were identified in Arabidopsis after its genome was successfully sequenced at the end of 2000 [79]. A typical mature plant RLK harbors an extracellular domain perceiving extracellular signal, a transmembrane region to anchor it in the plasma membrane, and a kinase domain containing conserved amino acid residues present in Ser/Thr kinases [80]. RLKs in Arabidopsis were classified into at least 14 families according to their diverse extracellular domains [81]. The most common extracellular motif is leucine-rich repeat (LRR) that is thought to be involved in protein-protein 
interaction [79]. The LRR-RLK family contains at least 223 members in Arabidopsis, and was classified into 15 subfamilies according to the number of extracellular LRRs [82,83]. Typical RLKs are plasma membrane-localized signaling molecules that perceive extracellular signals to regulate plant growth, development, and response to environmental stimuli [80]. RLKs may function as upstream regulators and interact with MAPKs to transduce the perceived signals via sequential phosphorylation, regulating plant immunity and development [31,84-86] (Figure 1). In this review, we discuss how RLKs function as upstream regulators to control plant development through the MAPK cascades.

\section{RLKs and MAPK Cascades Regulate Zygote Elongation, Asymmetric Division and Early Embryogenesis}

During early embryo development of Arabidopsis, the asymmetric division of the elongated zygote is an important event that determines the different developmental fate of the apical and basal cells. YODA (YDA), also known as MAPKKK4 in Arabidopsis, is a member of the MEKK subfamily. Loss-of-function of $Y D A$ leads to defective zygote elongation and apical-basal polarity of the embryo. The zygote of the $y d a$ mutant fails to elongate, resulting in two apical and basal cells with similar size. At the eight-cell stage, the $y d a$ embryo exhibits no obvious defects in the apical cell lineage but abnormal and short suspensor development. Oppositely, in plants with constitutively activated YDA (YDAac) the suspensor is longer than the wild type. Occasionally, the proembryo harboring YDAac shows irregular development or inhibited growth [87]. These data demonstrate that YDA-mediated signaling is essential for the asymmetric division of the zygote and early embryo development. Since the YDA-MKK4/5-MPK3/6 cascade was revealed in regulating stomatal development and patterning in Arabidopsis [31,88], it was reasonable to propose that MKK4/5 and MPK3/6 function as downstream signaling components of YDA during embryogenesis. Recently, it was shown that the $m k k 4 / 5$ double mutant exhibits strong defects in zygote elongation, asymmetric division of the zygote, and embryogenesis, similar to the $y d a$ mutant $[33,55]$. Similarly, the $m p k 3 / 6$ double mutant also generates an abnormal embryo without a distinguishable suspensor, similar to that of the $y d a$ and $m k k 4 / 5$ mutants [31]. These findings support that the YDA-MKK4/5-MPK3/6 signaling cascade controls zygote elongation, asymmetric division of the zygote, and development of the suspensor and early embryo proper in Arabidopsis (Figure 2A-C).

The WUSCHEL-RELATED HOMEOBOX (WOX) family transcription factors were found to be involved in early embryo development. In Arabidopsis, WOX2 and WOX8/9 are co-expressed in the zygote but restricted to the apical and basal cell, respectively [89,90]. The wox1/2/3/5 quadruple mutant loses the apical structures of the embryo; the wox $8 / 9$ double mutant shows abnormal division of the suspensor and the proembryo, resulting in arrested embryo development [90]. WRKY2, a zinc-finger transcription factor, can directly activate the transcription of WOX8 and regulate zygote polarization and basal cell division patterns during early embryogenesis [91]. A recent study revealed that the activated MPK3/6 interact with and directly phosphorylate WRKY2 to up-regulate WOX8 transcription in the zygote, which finally regulates zygote elongation and asymmetric division [92]. These results indicate that the YDA-MKK4/5-MPK3/6 signaling cascade regulates asymmetric zygote division and early embryo development by upregulating WRKY2-dependent expression of WOX8.

Some reports showed that RLKs are important regulators genetically upstream of canonical MAPK signaling cascades in controlling embryogenesis in plants. The sperm-originated and membrane-associated receptor-like cytoplasmic kinase (RLCK) SHORT SUSPENSOR (SSP) was reported as an upstream regulator of YDA in controlling elongation and asymmetric division of the zygote [93]. The ssp mutant shows similar but weaker embryonic defects when compared to the $y d a$ mutant, and hyperactive YDA can restore the suspensor phenotype of the ssp mutant [93]. Recent studies revealed that SSP genetically and biochemically interacts with YDA, and paternal SSP signaling activates the YDA-MPK3/6 cascade [86,92]. Defective zygote elongation and asymmetric division similar to ssp, $y d a$ and $m p k 3 / 6$ were also observed in the $m k k 4 / 5$ double mutant [33,55], indicating that MKK4/5 are key components in the SSP-YDA signaling pathway. All these findings demonstrate that 
SSP functions upstream of the YDA-MKK4/5-MPK3/6 cascade to regulate zygote polarity, elongation and asymmetric division (Figure 2A,B).

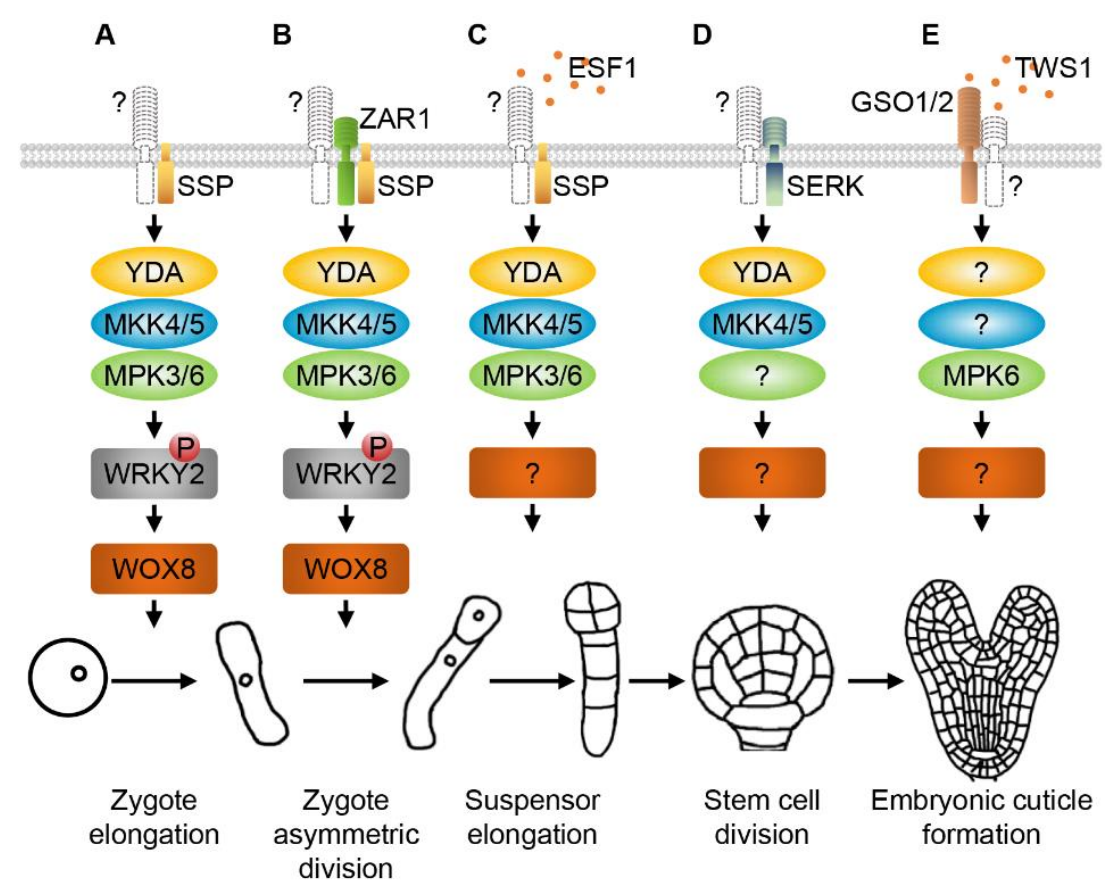

Figure 2. RLKs and MAPK cascades regulate embryo development. Membrane-associated receptor-like cytoplasmic kinase (RLCK) SHORT SUSPENSOR (SSP) regulates elongation of the zygote (A), asymmetric division of the zygote (B), and elongation of the suspensor (C) through the YDA-MKK4/5-MPK3/6 cascade. Leucine-rich repeat receptor-like protein kinase (LRR-RLK) ZYGOTIC ARREST 1 (ZAR1) is required to form a complex with SSP in controlling the asymmetric zygote division (B). The endosperm-secreted peptide EMBRYO-SURROUNDING FACTOR 1 (ESF1) regulates suspensor elongation together with SSP (C). A group of LRR-RLKs named SOMATIC EMBRYOGENESIS RECEPTOR-LIKE KINASES (SERKs) function upstream of YDA-MKK4/5 to control the division pattern of the ground tissue stem cells during early embryogenesis (D). The secreted peptide TWISTED SEED 1 (TWS1) is perceived by its receptor GASSHO1/2 (GSO1/2) to regulate embryonic cuticle formation through the YDA-MPK6 cascade (E). ? represents the unknown RLK, MAPK or transcription factor. $P$ indicates the phosphorylation of WRKY2.

ZYGOTIC ARREST1 (ZAR1), an LRR-RLK expressed in the central cell, egg cell, synergids, zygote and endosperm, is required for WOX 8 expression, and thus the asymmetric division of the zygote and the fate of the daughter cells [94]. The expression patterns of WOX2 and WOX8 are impaired in zar1. Consistently, no WRKY2 expression was detected in a zar1 mutant with strong phenotype [94]. In addition, The Arabidopsis G $\beta$ protein AGB1 functions as a scaffold protein to interact with ZAR1 and components of the YDA-MKK4/5-MPK3/6 cascade [86]. Moreover, ZAR1 can directly interact with SSP. These results demonstrate that a receptor complex formed by RLKs ZAR1 and SSP regulates zygote asymmetric division through the YDA-MKK4/5-MPK3/6 signaling cascade [86,94] (Figure 2B). Since the zar1 zygote does not show obvious elongation defects, it is possible that ZAR1 is not involved in zygote elongation.

EMBRYO-SURROUNDING FACTOR 1 (ESF1) peptide family contains three members, including ESF1.1 to 1.3, that are secreted small cysteine-rich peptides specifically expressed in the central cell and embryo-surrounding endosperm cells [95]. RNA interference (RNAi) lines down-regulating the expression of three ESF1 members show variable embryo proper patterning defects and a shortened suspensor, suggesting that the endosperm-secreted ESF1 peptides possibly regulate early embryo development in a non-cell-autonomous manner. In addition, genetic analyses revealed that ESF1 
peptides function upstream of SSP and YDA to regulate suspensor length. Furthermore, reciprocal cross assays between esf1 and single fertilization mutants lacking endosperm found that maternally produced ESF1 peptides in the central cell and endosperm are essential for early embryogenesis [95]. Collectively, these findings suggest that the extraembryonic maternal factor ESF1 may be perceived by a yet unknown receptor in the zygote and early embryo to control suspensor development through the SSP-YDA-MKK4/5-MPK3/6 signaling cascade (Figure 2C).

\section{SERKs and MAPKs Regulate Division Patterns of Embryonic Stem Cells}

During embryo development, the vascular precursors and ground tissue stem cells undergo transverse and asymmetric divisions to produce daughter cells that renew the stem cells and form the vascular tissue, endodermal cells, and cortical cells. For a long time, little was known about the underlying molecular mechanisms that strictly regulate the division of the stem cells. Although SOMATIC EMBRYOGENESIS RECEPTOR-LIKE KINASES (SERKs), a subfamily of LRR II-RLKs with a short extracellular domain containing five LRRs, have been discovered to be coreceptors of various RLKs in regulating many aspects of plant growth, development, and immunity [49,54,96-106], no evidence supported that SERKs regulate stem cell fate during embryo development.

Recently, however, a study demonstrated that SERKs control early embryogenesis in Arabidopsis [55]. The serk1/2/3 triple mutant generates an arrested embryo because of the defective first asymmetric division of the vascular precursors and the abnormal second asymmetric division of the ground tissue stem cells. Interestingly, both the constitutively activated YDA and MKK5 can partially suppress the division defects of the ground tissue stem cells in the serk $1 / 2 / 3$ embryo [55]. This study uncovered that SERKs and YDA-MKK4/5 function in the same signaling pathway to control cell fate of the ground tissue stem cells during early embryogenesis (Figure 2D). As mentioned above, MPK3/6 function downstream of YDA and MKK4/5 to regulate zygote elongation, the asymmetric division of the zygote, and suspensor development during early embryogenesis [33,86,92]. However, whether MPK3/6 are involved in regulating stem cell division and fate determination in embryogenesis still needs further investigation. On the other hand, the proposed ligand and receptor involved in this process have not been identified yet.

\section{GSO1/2 and MAPKs Modulate Embryonic Cuticle Formation}

The cuticle formed during embryogenesis surrounds the embryo and plays a critical role in preventing the embryo from fusing with the endosperm, which provides a relatively independent environment for proper embryo development. In the past decade, several key genes were identified in modulating embryonic cuticle formation. Loss-of-function of GASSHO1 (GSO1) and GSO2, two homologous LRR-RLKs with a long extracellular domain, results in seeds more twisted than the wild type. Detailed phenotypic analyses revealed that the cotyledons of the gso1/2 double mutant adhere to each other and the endosperm tissue around the embryo at the late torpedo stage, and the mature embryo finally bends in reverse. Staining analysis showed that epidermis permeability of the cotyledons is impaired in the gso1/2 double mutant because of defective cuticle formation during embryo development, which is at least partly responsible for the observed organ adhesion [107].

Recently, TWISTED SEED 1 (TWS1) was found to participate in the GSO1/2 signaling pathway as a non-cell-autonomous peptide hormone to modulate embryonic cuticle deposition on epidermal cells [108]. TWS1 is an embryo-expressed small peptide containing 81 amino acid residues. The tws 1 mutant produces twisted seeds and abnormal cotyledons adhered to the endosperm, similar to the $g s 01 / 2$ double mutant [109]. Embryo-expressed TWS1 precursors move into the endosperm where they are modified by ABNORMAL LEAF-SHAPE 1 (ALE1), a subtilisin-like serine protease whose expression is controlled by the transcription factor ZOUPI (ZOU), to generate mature TWS1 peptides $[108,110,111]$. Then, the mature TWS1 peptides are perceived by the receptors GSO1/2 in epidermal cells of the embryo. The TWS1-GSO1/2-mediated dialogue between the embryo and endosperm is essential for proper cuticle deposition on the embryo [108]. 
It was reported that the mpk6 mutant also exhibits seed defects [112]. In addition, the phosphorylation level of MPK6 in $g s 01 / 2$ seeds is significantly reduced compared to the wild type [113]. Moreover, the gso1/2 mpk6 triple mutant produces concave seeds and defective cotyledons with altered permeability, which is similar to the $g s 01 / 2$ double mutant. The impaired cotyledon permeability in the ale1 mpk6 double mutant is not enhanced when compared with ale1-4 [113]. The current findings support that MPK6, GSO1/2, and ALE1 may function in a common pathway, and MPK6 may act downstream of the GSO1/2-mediated signaling pathway [113]. The embryo of the $y d a$ and $m k k 4 / 5$ mutants also bends in reverse when compared with the wild type [55,87], suggesting that the YDA-MKK4/5-MPK6 cascade may also function downstream of TWS1-GSO1/2 to modulate cuticle deposition on the embryo, although further studies are still required in the future (Figure 2E). GSO1/2 also function as the receptor of two small peptides, CASPARIAN STRIP INTEGRITY FACTOR 1 (CIF1) and CIF2, to regulate the formation of the Casparian strip diffusion barrier [114,115]. A recent study suggested that SERKs may be involved in the CIF1/2-GSO1/2 signaling pathway as a coreceptor [116]. Whether SERKs function together with GSO1/2 to transduce the TWS1 signal in modulating embryonic cuticle deposition is worth further investigating in the near future.

\section{ER family RLKs and MAPKs Regulate Anther Development}

In Arabidopsis, the diploid archesporial cells are formed in the L2 layer of the anther primordia. They divide and develop to form four lobes of the anther. Absence or defects in the archesporial cells usually lead to failure of the anther lobes and thus the male gametophytes. SPOROCYTELESS/NOZZLE (SPL/NZZ) is a crucial regulator of the archesporial cells. The loss function mutant $s p l / n z z$ shows defects in initiation and differentiation of both the microsporocytes and megasporocytes [117,118]. Ectopically expressed SPL/NZZ can induce microsporocytes in petals of the agamous mutant [119]. Some studies revealed reduced male fertility in $m p k 6$ and the double $m p k 3^{++} m p k 6$ mutant. Anthers of the $m p k 6$ and $m p k 3^{++} m p k 6$ mutants are significantly smaller than those of the wild type, and the pollen grains of $m p k 6$ are associated with the anther more tightly than the wild type, which suggests that MPK3/6 are involved in anther development of Arabidopsis [8,57]. In vitro and in vivo assays revealed physical interactions between SPL and MPK3/6 recently. In addition, MPK3/6 can phosphorylate SPL in vitro, and the phosphorylation of SPL by MPK $3 / 6$ is crucial for its functions in Arabidopsis anther development [120]. These results also suggest that additional components of the MPK3/6 cascade may be involved in anther development (Figure 3A).

ERECTA-family (ERf) RLKs, including ER, ERECTA-LIKE 1 (ERL1), and ERL2, have been discovered as essential regulators to control anther development. The er erl1/2 triple mutant has small and incompletely differentiated anthers in flowers at stage 9 [121]. Both the er erl1/2 and $m p k 3^{++}$ mpk6 mutants show some similar anther defects. For example, both of them fail to form one or more of the four anther lobes. Collectively, ERf-RLKs and MPK3/6 may function in a common signaling pathway and play important roles in specifying the archesporial cell identity or maintaining functions of the archesporial cells to generate the progeny cells [8] (Figure 3A). Some other LRR-RLKs were also found to be involved in anther development. For instance, EXTRA SPOROGENOUS CELLS (EXS)/EXCESS MICROSPOROCYTES 1 (EMS1) and SERK1/2 form a receptor/coreceptor complex that perceives the TAPETUM DETERMINANT1 (TPD1) peptide signal to control the differentiation of the microsporocytes and tapetal cells [104,122-126]. BARELY ANY MERISTEM 1/2 (BAM1/2) regulate the differentiation of the L2-derived cell types during microsporogenesis [127]. RECEPTOR-LIKE PROTEIN KINASE 2 (RPK2) guarantees the specification of the middle layer during early anther development [128]. Recently, it was reported that CLAVATA3 INSENSITIVE KINASE 1/2/3 (CIK1/2/3) function as coreceptors of BAM1/2 and RPK2 to regulate early anther development [129]. However, it is not known whether these RLKs affect archesporial cell initiation and differentiation through MAPK signaling. 


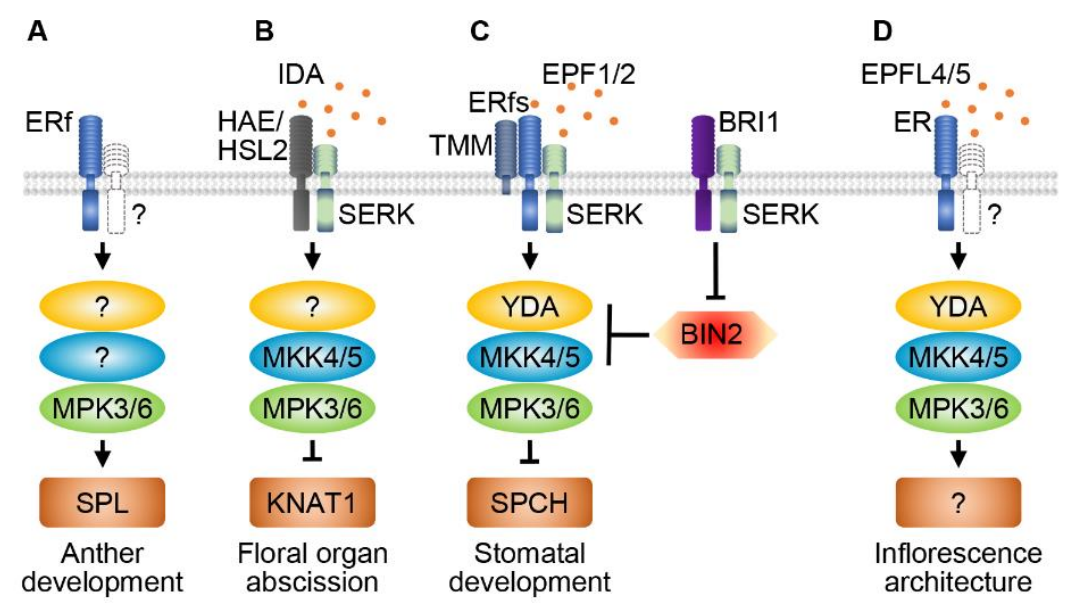

Figure 3. RLKs and MAPK cascades regulate reproductive and stomatal development. ERECTA family (ERf) members and MPK3/6 modulate anther development via activating the transcription factor SPOROCYTELESS (SPL) (A). HAESA/HAESA-like 2 (HAE/HSL2) and coreceptor SERKs perceive the INFLORESCENCE DEFICIENT IN ABSCISSION (IDA) peptide signal to control floral organ abscission by activating MKK4/5 and MPK3/6 (B). ERf, TOO MANY MOUTH (TMM) and SERKs form a receptor complex to sense the EPIDERMAL PATTERNING FACTOR 1/2 (EPF1/2) peptide ligands to control stomatal development and pattern via the YDA-MKK4/5-MPK3/6 cascade. BRASSINOSTEROID-INSENSITIVE 2 (BIN2) functions downstream of BRASSINOSTEROID INSENSITIVE 1 (BRI1) to repress the activity of YDA and MKK4/5 in controlling stomatal development (C). ER perceives the EPF-LIKE 4/5 (EPFL4/5) peptide signals to regulate inflorescence architecture via the YDA-MKK4/5-MPK3/6 cascade (D). ? represents the unknown RLK, MAPK or transcription factor.

\section{RLKs and MAPK Cascades Regulate Organ Abscission}

There is a small proportion of cells forming the abscission zone (AZ) in plants, which is the boundary between an organ and the plant, necessary for abscission to take place when the organ is senescent [130]. A peptide ligand-receptor system was found to regulate floral organ abscission in Arabidopsis. The haesa haesa-like 2 (hae hsl2) double mutant fails to abscise its floral organs, which is similar to the inflorescence deficient in abscission (ida) mutant [131-133]. Neither overexpression of IDA nor application of synthetic IDA peptide can rescue the abscission deficiency of hae hsl2, indicating that HAE and HSL2 are genetically epistatic to IDA, and IDA and HAE/HSL2 may control floral organ abscission through the same signaling pathway in Arabidopsis [131]. Further structural and biochemical analyses revealed that HAE functions as the receptor to transduce the IDA signal [101].

The $m k k 4 / 5 R N A i$ mutant and a $m p k 6$ dominant-negative mutant in the $m p k 3$ background produce non-abscising flowers, whereas constitutively activated MKK4/5 rescue the abscission-defective phenotype of the hae $h s l 2$ and ida mutants, suggesting that the MKK4/5-MPK3/6 cascade functions downstream of IDA-HAE/HSL2 in regulating organ abscission [32] (Figure 3B). However, whether YDA is also involved in the MKK4/5-MPK3/6 signaling cascade to control floral organ abscission is not known. Once the abscission program is initiated, AGAMOUS-like 15 (AGL15), a putative transcriptional repressor, is differentially phosphorylated through floral development by the MKK4/5-MPK3/6 signaling, which increases the expression of $H A E$, thus controlling the organ abscission process via a positive feedback loop [134]. All the $i d a$, hae $h s l 2$, and $m k k 4 / 5$ RNAi mutants exhibit defective drought-induced leaf abscission, indicating that the IDA-HAE/HLS2-MKK4/5 signaling is also necessary for drought-induced leaf abscission in Arabidopsis [135].

Two other regulators, EVERSHED (EVR), an LRR-RLK also known as SUPPRESSOR OF BIR1 1 (SOBIR1), and NEVERSHED (NEV), an ADP ribosylation factor, also play important roles in regulating the time of floral organ abscission in Arabidopsis by restricting the AZ cell size. The AZ is extended and organs abscise prematurely in the double nev evr mutant [136]. However, genetic analyses uncovered that mutation in EVR cannot rescue the abscission defects of $i d a$ and hae hsl2 [136], implying that 
IDA-HAE/HSL2 may function in a parallel pathway with EVR and NVR, or EVR and NVR may act upstream of the IDA-HAE signaling pathway to regulate floral organ shedding. KNOTTED-LIKE FROM ARABIDOPSIS THALIANA 2/6 (KNAT2/6), two KNOTTED-like homeobox transcription factors, are activators of floral organ separation and suppressed by KNAT1 that is inactivated by the IDA signaling pathway [137]. Collectively, all these findings provide the evidence that IDA-HAE/HSL1/2 regulates KNATs through the MKK4/5-MPK3/6 cascade to timely modulate organ abscission (Figure 3B).

Three triple serk mutants, serk1-1 serk2-1 bak1-5, serk1-1 bak1-5 serk4-1, and serk1-1 serk2-1 bak1-4, exhibit defective floral organ abscission, similar to the $i d a$ and hae hsl 2 mutants, while the triple mutants serk1-1 serk2-1 serk4-1 and serk2-1 bak1-5 serk4-1 have normal floral organ abscission, indicating that these SERKs function redundantly and differentially to regulate organ abscission, and SERK1 and BAK1 are more important in this biological process [54]. Overexpression of IDA in the serk1-1 serk2-1 bak1-5 mutant cannot rescue the floral organ abscission defects. Biochemical assays showed that SERKs can directly interact with HAE/HSL2, which can be enhanced by application of the IDA peptide, and IDA, HAE/HSL2 and SERKs can form a complex. Moreover, BAK1 and HAE transphosphorylate each other in their cytosolic domains [101]. These results demonstrate that SERKs function as coreceptors of HAE/HSL2 in regulating floral organ abscission, which is also supported by structural results that HAE can bind the IDA peptide more effectively in the presence of SERK1 [54,101]. In addition, constitutively activated MKK5 can restore the floral organ abscission defects of serk1-1 serk2-1 bak1-5. The current knowledge supports that SERKs are co-receptors of HAE/HSL2 in perceiving IDA, and function upstream of the MKK4/5-MPK3/6 cascade to regulate floral organ abscission (Figure 3B).

Interestingly, the regulation of organ abscission by peptide hormones has been also found in other plants. A very recent study revealed that the tomato (Solanum lycopersicum) phytosulfokine (PSK) signal is involved in stress-induced flower drop [138]. PSK was first described in Asparagus as a unique plant peptide growth factor [139]. Further studies suggested that the PSK signaling participates in plant growth and immunity $[140,141]$. Overexpressed phytaspase 2 (SIPhyt2), a precursor-processing protease of SIPSK, leads to premature abscission of flowers in tomato, and flower abscission increases to $70 \%$ as compared to $50 \%$ in the wild type under drought stress [138]. However, IDA seems not to contribute to stress-induced flower abscission in tomato because the expression of five IDA precursor genes is very low in the abscission zone and does not respond to drought stress [138]. Different from the IDA-regulated drought-induced leaf abscission in Arabidopsis [135], this study provides an insight on peptide hormone signaling in regulating the abscission process in other plants, although the downstream signaling components of SIPSK are still unknown.

\section{RLKs and MAPKs Regulate Stomatal Patterning and Development}

In Arabidopsis, the stomatal lineage begins with meristemoid mother cells (MMCs) transformed from a subset of protodermal cells. An MMC undergoes an asymmetric division to produce a smaller triangular meristemoid and a larger stomatal-lineage ground cell (SLGC). The SLGC can become a lobed pavement cell or initiate another asymmetric division to produce a satellite meristemoid that is oriented away from a stomatal precursor. The meristemoid loses its ability to reiterate asymmetric division after a variable number of amplifying divisions, then the meristemoid differentiates into a guard mother cell (GMC). The GMC divides once symmetrically to generate two guard cells. The mature guard cells control the size of the stomatal opening [142-145].

Small secretory peptide EPIDERMAL PATTERNING FACTOR 1 (EPF1) expressed in stomatal precursor cells was identified to control stomatal patterning by regulating asymmetric cell division. Overexpression of EPF1 results in decreased stomatal density, while clustering of stomata and increased stomatal density exist in the epf1 mutant [146]. The secretory peptide EPF2 that is related to EPF1 is expressed in MMCs, meristemoids, and GMCs to negatively regulate stomatal development. Overexpression of EPF2 results in dramatically decreased stomata $[147,148]$. STOMAGEN, a peptide also known as EPF-LIKE 9 (EPFL9), was found to regulate stomatal development in another way. Different from EPF1/2, STOMAGEN is expressed in inner tissues of immature leaves instead of 
the epidermis. The stomatal density is reduced in leaf epidermis of the stomagen mutant [149-151]. STOMAGEN can bind the receptors by competing with EPF2 to antagonize the signaling pathway [152]. The ERf RLKs have been identified as the receptors of EPF peptides in regulating stomatal development [152,153]. Stochastically distributed and excess stomatal clusters are formed in cotyledon epidermis of the er erl1 erl2 triple mutant. No double mutants of ERf members exhibit a phenotype with excess stomata similar to the er triple mutant [154,155], indicating that ER, ERL1, and ERL2 play an essential and redundant role for stomatal patterning and development. TOO MANY MOUTH (TMM), an LRR type receptor-like protein, was reported to suppress stomatal initiation together with the protease STOMATAL DENSITY AND DISTRIBUTION 1 (SDD1). The mutations in TMM cause clustered stomata and disrupted one-cell spacing stomatal patterning [88,143,156-159].

The serk1-1 serk2-1 bak1-4 triple mutant produces clustered stomata in cotyledon epidermis, which is similar to the er erl1 erl2 triple mutant $[99,154,155]$. BAK1 is the most important SERK in regulating stomatal development because the serk double or triple mutants containing mutation in BAK1 can cause stomatal defects similar to the er triple mutant. Moreover, SERKs interact with ERfs and TMM, and EPFs can induce the interaction between SERKs and ERfs. In addition, exogenous application of EPF1/2 peptides cannot alleviate the stomatal defects. These results suggest that SERKs function as coreceptors of ERfs to control stomatal patterning and development [99].

MAPKs play essential roles in regulating stomatal pattern. YDA activity inhibits protodermal cells entering the stomatal lineage. However, YDA activity is required to regulate the generation of GMCs by meristemoids. Null yda mutants produce excess stomata [88]. On the other hand, constitutively activated YDA can suppress the stomatal phenotype of serk1/2 bak1, tmm and sdd1 [88,99]. The $m k k 4 / 5$ RNAi plants show dramatic defects in stomatal development and patterning, with extensive excess stomata and no pavement cells, which is similar to the $y$ da mutant. Accordingly, constitutively activated MKK4/5 inhibit stomatal cell fate initiation in the wildtype background, and greatly suppress the clustered stomata phenotype in the $y d a$ mutant. Similar to $y d a$ and $m k k 4 / 5$, the mpk6 mpk3RNAi mutants produce excess stomata [31]. These data demonstrate that the YDA-MKK4/5-MPK3/6 signaling cascade acts downstream of the ERf-SERK receptor complex and plays a critical role to coordinate cell fate specification during stomatal development and patterning (Figure 3C). Another study showed that constitutively activated MKK7/9 in the MMCs can inhibit guard cell initiation, which is similar to that of constitutively activated MKK4/5. However, constitutively activated MKK7/9 driven by a GMC-specific promoter results in excess stomata. These results suggest that MKK7/9 may play an essential role in regulating guard cell initiation [160]. It is still unknown whether MKK7/9 function downstream of the ERf-SERK receptor complex.

Some studies revealed that brassinosteroid signal is also involved in regulating stomata formation because clustered stomata are produced in the brassinosteroid biosynthetic mutant constitutive photomorphogenic dwarf ( $c p d$ ), the receptor mutant bri1, and the gain-of-function signaling mutant bin2-1 [161], respectively. BIN2, a shaggy-like kinase and key negative regulator in the brassinosteroid signaling pathway, can phosphorylate MKK4 to inhibit the MPK6 activity [162]. Another study indicated that BIN2 functions as a negative regulator of the MAPK cascade by phosphorylating YDA to control stomatal pattern and development. Furthermore, physiological and genetic assays suggested that BIN2 acts downstream of BRI1, but upstream of YDA-MKK4/5-MPK3/6, to regulate stomatal development [53]. These results imply that the YDA-MKK4/5-MPK3/6 cascade coordinates the brassinosteroid and EPF peptide signals to control stomatal pattern and development (Figure 3C). Recently, a study revealed that MAPKKK3 and MAPKKK5 transduce immune signals to the downstream module MKK4/5-MPK3/6, and this pathway and the YDA-MKK4/5-MPK3/6 signaling can antagonize each other [163], suggesting that different MAPK cascades, even though they share some signaling components, can coordinate immune responses and development processes.

SPEECHLESS (SPCH) is a bHLH transcription factor with a MAPK target domain, which can be phosphorylated by MPK3/6 in vivo [164]. No stomata can be formed in the spch mutant, similar to the phenotype of transgenic plants with constitutively activated YDA and MKK4/5 $[31,88,165]$. However, 
overexpression of SPCH without the MAPK target domain can produce excess stomata in the mpk6 and erl1 erl2 mutants [164]. Thus, SPCH functions as a crucial transcription factor downstream of the ERf-YDA-MKK4/5-MPK3/6 signaling pathway to control stomatal pattern (Figure 3C). Interestingly, it seems that different transcription factors may be employed by the MAPK cascade to regulate stomatal patterns in different plants. For example, Brachypodium distachyon BdYDA1 was reported to promote stomatal spacing patterning in Brachypodium. However, instead of BdSPCH1 and BdSPCH2, Brachypodium INDUCER OF CBF EXPRESSION 1 (BdICE1) that is expressed in the stomatal lineage cells, is a more likely the target of BdYDA1 [42].

\section{RLKs and MAPK Cascades Regulate Root Development}

MAPK cascades are also involved in signaling during Arabidopsis root development. Expression pattern analysis showed that MPK6 is highly expressed in the meristem and transition zone of Arabidopsis roots [58]. Three mpk6 knock-out mutants exhibit no root or short-root phenotypes. Disordered cell files caused by ectopic cell divisions were observed in the roots of $m p k 6$ [58]. Intriguingly, another study found that mutation in MPK6 produces three types of seed: bigger seeds, smaller raisin seeds, and burst seeds. The seedlings from smaller raisin seeds show a short-root phenotype. However, the seedlings from bigger seeds have a longer primary root than that of the wild type, accompanied by increased lateral root initiation, and more and longer root hairs [112]. All these findings suggest that MPK6 plays critical roles during primary and lateral root development. Disordered cell files also result in thickened and short roots in $y d a$ [60]. Arabidopsis ANP1/2/3, the homologous MAPKKK genes of tobacco NPK1, were found to regulate cell division and growth [166]. The anp2/3 double mutant exhibits defects in the root, which is caused by impaired microtubule organization [67]. The null mpk4 mutant also shows microtubule-related phenotypes, such as cytokinetic defects in the primary root, which is similar to anp2/3 $[67,167]$. Therefore, ANP2/3 may function upstream of MPK4 in controlling microtubule organization that affects root development. ABA-INSENSITIVE PROTEIN KINASE 1 (AIK1), a MAPKKK also known as MKKK20, is necessary for controlling cell division and elongation during primary root development. Roots of the aik1 mutant are insensitive to abscisic acid treatment [168]. Biochemical analyses provided evidence that MKKK20 can interact with MKK3 and MPK18. Moreover, MKKK20 can phosphorylate MKK3 and MPK18. Primary roots of the $m k k k 20 m p k 18$ and $m k k 3 m p k 18$ double mutants are shorter than single mutants under treatment of microtubule-disrupting drugs. All these data suggest that the MKKK20-MKK3-MPK18 cascade is required for microtubule function in the root [27].

Several RLKs were reported to regulate primary and lateral root development. For example, ARABIDOPSIS CRIKLY 4 (ACR4) perceives the CLE40 peptide to regulate root meristem differentiation via controlling the size and position of root stem cell niche [169]. FERONIA (FER) functions as the receptor of peptide Rapid Alkalinization Factor 1(RALF1) to regulate root growth, which may be related to endocytosis of plasma membrane proteins $[170,171]$. MUSTACHES (MUS) and MUSTACHES-LIKE (MUL), two LRR-RLKs, modulate lateral root primordial development by controlling the biosynthesis and remodeling of the cell wall [172]. However, there is no evidence yet that these RLKs regulate root development through MAPK cascades.

Recently, several studies revealed that MAPK signaling pathways also function downstream of RLKs to regulate primary root development. ROOT MERISTEM GROWTH FACTORS (RGFs) are a group of quiescent center-expressed Tyr-sulfated peptides that regulate primary root development via controlling root meristem size. Roots of the $r g f$ mutants are extremely short, demonstrating that RGFs are crucial to postembryonic root development [173]. RGF1 INSENSITIVES/RGF RECEPTORS (RGIs/RGFRs) are a clade of LRR-RLKs containing five members, which function as receptors of RGF1 to regulate root meristem $[100,102,174]$. The primary root of the $r g i 1 / 2 / 3 / 4 / 5$ quintuple mutant is significantly shorter than the wild type because of the shrunken root meristem. Moreover, the rgi quintuple mutant is insensitive to RGF1 treatment. Upon perception of RGF1, phosphorylation and ubiquitination of RGI1 occur to transduce the signal. These findings demonstrate that RGIs sense the RGF1 signal, which 
is crucial for maintaining root meristem size and primary root development [100]. The stability of RGIs is strictly regulated by two ubiquitin-specific proteases, UBP12 and UBP13. UBP13 can directly interact with RGI1 and counteract the ubiquitination and degradation of RGI1 [175]. The $u b p 12 / 13$ double mutant is completely insensitive to RGF1 treatment, similar to the rgi quintuple mutant [175]. Genetic, biochemical and structural results revealed that RGIs recruit SERKs as coreceptors to perceive the RGF1 signal in regulating root meristem $[100,102,174]$. A very recent study revealed that constitutively activated YDA can rescue the phenotype of the $r g i 1 / 2 / 3 / 4 / 5$ mutant. The $m k k 4 / 5$ double mutants exhibit a smaller root meristem, a defect very similar to $r g i 1 / 2 / 3 / 4$. Moreover, the $m k k 4 / 5$ mutants are partially insensitive to RGF1 treatment, suggesting that MKK4/5 may regulate root meristem size in the same signaling pathway with RGIs. Genetic and physiological analyses further implied that MPK3/6 control root meristem size downstream of MKK4/5 [176,177]. The expression of PLETHORA1/2 (PLT1/2), two critical transcription factors regulating root stem cell niche [178], is dramatically reduced in both of the rgi quintuple and $m k k 4 / 5$ double mutants $[100,176]$. These data suggest that the RGI-SERK receptor complex senses the RGF1 signal to regulate root meristem size and primary root development through the YDA-MKK4/5-MPK3/6 signaling cascade (Figure 4A).

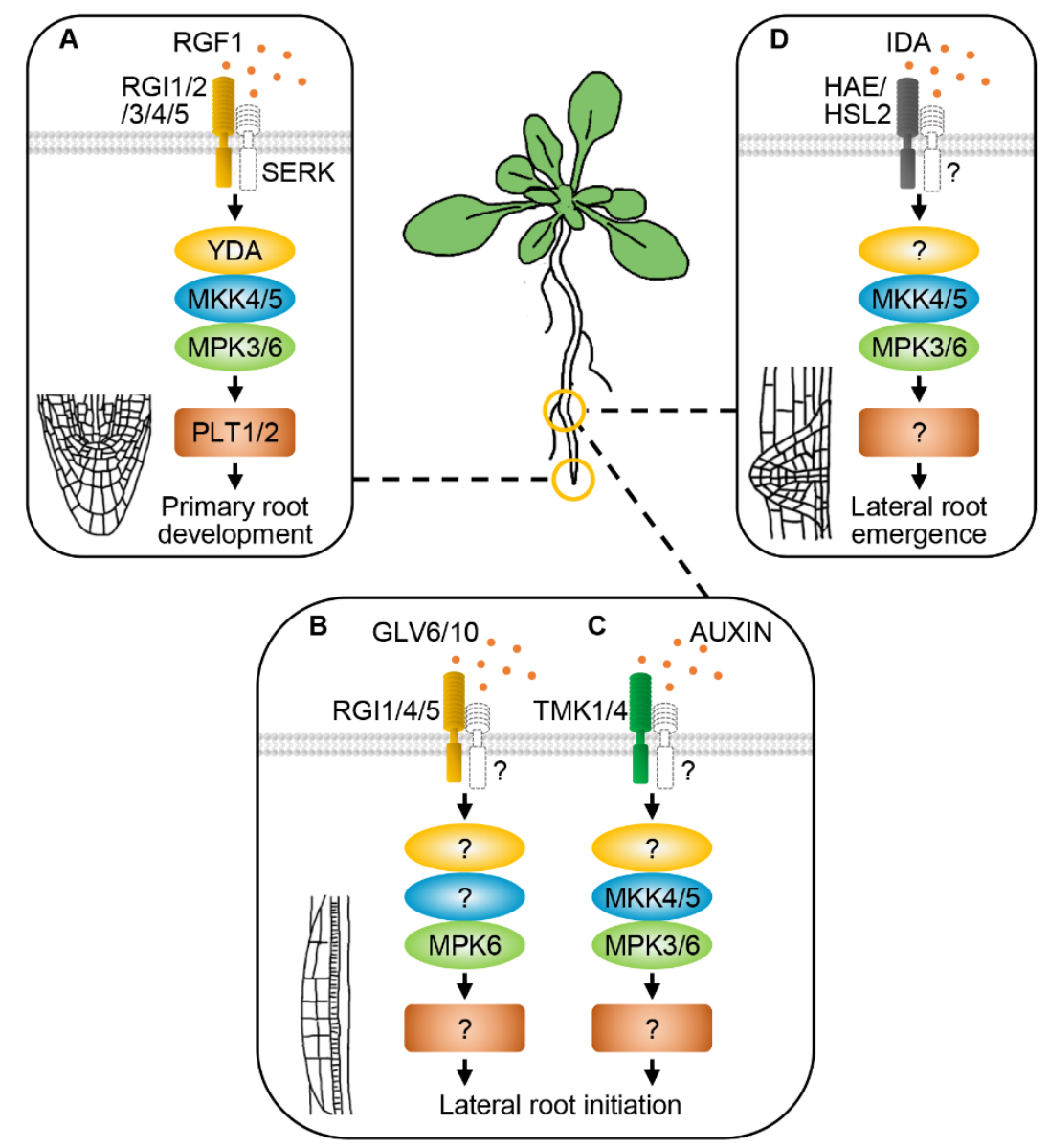

Figure 4. RLKs and MAPK cascades regulate root development. ROOT MERISTEM GROWTH FACTOR 1 (RGF1) INSENSITIVES (RGIs) and SERKs form a receptor complex to perceive the RGF1 peptide signal in regulating primary root development through the YDA-MKK4/5-MPK3/6 cascade (A). RGI1/4/5 and their ligands GOLVEN 6/10 (GLV6/10) control lateral root initiation by activating MPK6 (B). TRANSMEMBRANE KINASES 1/4 (TMK1/4) perceive auxin to regulate lateral root initiation through the MKK4/5-MPK6 cascade (C). The IDA-HAE/HSL2 ligand-receptor pairs act upstream of MKK4/5-MPK3/6 to regulate lateral root emergence (D). ? represents the unknown RLK, MAPK or transcription factor. 
RGF peptides are also required for lateral root initiation. GOLVEN 6 (GLV6), also named RGF8 and CLE-LIKE 2 (CLEL2), is expressed in early steps of the formation of lateral root primordium. Overexpression of GLV6 results in decreased emergence of lateral roots. Treatment with the GLV6 peptide impairs the first asymmetric cell division during primordium formation [179]. Recently, GLV6/10 were found to participate in lateral root initiation, and RGI1/4/5 may function as receptors of GLV6/10 in controlling this process. Loss-of-function of GLV6/10 increases the asymmetric cell division during lateral root initiation. Consistently, seedlings overexpressing GLV6 lack visible lateral roots because of ectopic anticlinal division of pericycle cells. However, defective pericycle divisions caused by GLV6 overexpression are suppressed in the mpk6 mutant. Moreover, GLV6 can induce MPK6 phosphorylation and activation, which is dependent on the RGI receptors [180]. These results indicate that MPK6 is a downstream effector of the GLV6/10-RGI1/4/5 pathway during lateral root initiation (Figure 4B).

Extracellular auxin perception and signaling can be mediated by TRANSMEMBRANE KINASES (TMKs), a group of LRR-RLKs, to regulate apical hook formation in Arabidopsis, representing a new mechanism of auxin perception [181]. Exogenous auxin can induce lateral root initiation in the wild type, but is ineffective in the tmk1/4 double mutant. The $m k k 4 / 5$ mutants are also insensitive to exogenous auxin regarding lateral root initiation. Biochemical assays showed that TMK1/4 can bind MKK4/5. Moreover, auxin can induce the phosphorylation of MKK4/5 and MPK3/6, which depends on TMK1/4. Taken together, these data indicate that auxin signaling regulates lateral root initiation also via the MKK4/5-MPK3/6 cascade [182] (Figure 4C).

Lateral roots can be properly formed only when the initiated primordia successfully develop and go through the surrounding cell layers. The ida, hae, and hsl2 single mutants display reduced lateral root density, implying that HAE and HSL2 regulate lateral root development possibly through different pathways. IDA and HAE regulate the degradation of pectin, a component of cell wall. IDA, HAE, and HSL2 together regulate the transcription of cell wall remodeling genes. Collectively, the ligand-receptor complex IDA-HAE/HSL2 is necessary for lateral root emergence [183]. Recently, it was reported that the $m p k 3 / 6$ double mutant exhibits reduced lateral root density, a similar phenotype found in the $m k k 4 / 5$ mutant [56]. Detailed analyses revealed that the lateral root primordia fail to go through the endodermis, cortex and epidermis in $m p k 3 / 6$ and $m k k 4 / 5$, which results in the reduced lateral root density. Meanwhile, constitutively activated MKK4/5 driven by a HAE or HSL2 promoter can rescue the emergence defects of lateral roots in the ida and hae hsl2 mutants [56]. In summary, the current results support that the IDA signal is perceived by HAE/HSL2 to regulate lateral root emergence through the MKK4/5-MPK3/6 signaling cascade (Figure 4D).

\section{RLKs and MAPK Cascades Function in Other Plant Developmental Processes}

The shoot apical meristem (SAM) contains a collection of undifferentiated cells, which produces primordia developing into all the above-ground organs of a plant. RLKs and MAPKs are also involved in maintaining the SAM. Overexpression of MKK7 leads to collapsed and defective SAM. The process of de-etiolation induced by light is enhanced in the $m k k 7$ and $m p k 6$ mutants, suggesting that MKK7 and MPK6 function as negative regulators of meristem activity [36]. The CLAVATA-WUSCHEL (CLV-WUS) feedback loop is the classic regulatory pathway that maintains the homeostasis of the SAM [184,185]. The CLV3 peptide signal is transduced by RLKs, including CLV1 and RPK2, and CLV2/CORYNE (CRN) heterodimer consisting of the receptor-like protein CLV2 and the receptor-like cytoplasmic protein kinase CRN, to repress the expression of transcription factor WUS. CIKs, another group of LRR-RLK, function as coreceptors of CLV1, RPK2 and CLV2/CRN to maintain the SAM [186]. However, how the CLV3 signal is transmitted from the receptors on the plasma membrane to the nucleus-localized WUS is still largely unknown. It was reported that the CLV3 signaling can activate MPK6 to maintain SAM homeostasis [187]. A recent study showed that exogenous CLV3 can activate MPK3/6, and the $m p k 3 / 6$ double mutant is insensitive to CLV3 treatment [10]. The transcription levels of WUS-target genes, such as ARABIDOPSIS RESPONSE REGULATOR 7/15 (ARR7/15), GROWTH-REGULATING FACTOR 6 
(GRF6) and YABBY 3 (YAB3), are decreased in mpk3/6. Treatment with the CLV3 peptide can inhibit the SAM in the wild type. However, the SAM is still normal in most $m p k 3 / 6$ mutants treated with exogenous CLV3. Moreover, the size of the SAM in $m p k 3 / 6$ is larger than the wild type [10]. All these findings suggest that the CLV3-CLV1 signaling pathway regulates stem cell homeostasis in the SAM possibly via activating a MAPK cascade including MPK3/6.

The ERf members regulate several biological processes, including male and female reproductive organ development, stomatal development, and inflorescence architecture [121,144]. Loss-of-function mutation in $M P K 3 / 6$ and $M K K 4 / 5$ results in clustered inflorescence, which is similar to the er mutant. The er-105 mpk6 double mutant exhibits enhanced inflorescence defects when compared with the er-105 single mutant. Moreover, gain-of-function of MPK3/6 can rescue the inflorescence defects of the er mutant. The constitutively activated MKK4/5 and YDA can also at least partially rescue the inflorescence defects of the er mutant, generating elongated inflorescences and pedicels when compared with $e r-105$. These results support that the YDA-MKK4/5-MPK3/6 cascade functions downstream of the ER signaling pathway to regulate inflorescence architecture in Arabidopsis [84] (Figure 3D).

Regulation of MAPK cascades by ER has been found in other species. The small grain 1 (smg1) mutant with decreased grain size was identified in rice (Oryza sativa) through a forward genetic screening, which contains a mutation in OsMKK4 [188]. A rice MAPK cascade consisting of OsMKKK10, OsMKK4, and OsMPK6 was further identified, which functions to control grain size [189]. A very recent study found that OsERECTA (OsER), a homologous protein of Arabidopsis ER in rice, is involved in controlling the spikelet number per panicle. The spikelet number per panicle is increased and the grain size is reduced in the oser mutant. Constitutively activated OsMKKK10 and OsMKK4 can rescue the increased spikelet number phenotype of oser, and induce the phosphorylation of OsMPK6 in oser. Collectively, OsER acts upstream of the OsMKKK10-OsMKK4-OsMPK6 cascade to control the spikelet number per panicle and grain size [190], which has the potential to be applied in rice agriculture.

\section{Conclusions and Future Perspectives}

MAPK cascades have always been one topic gaining more attention in the research field of signal transduction in plants. Many plant MAPK cascades have already been identified and extensively investigated in the past decades [3,191,192]. However, the upstream signaling components regulating MAPK modules involved in plant growth and development were not effectively identified for a long time. In recent years, RLKs have been revealed to function as key upstream regulators of MAPK cascades to perceive extracellular signals and transduce them to downstream signaling pathways [8,10,53-55,93-95,113,164,176,177,182].

However, the upstream regulators of some known MAPK cascades involved in plant development have not been identified and characterized yet. For example, the MKK7-MPK6 cascade regulates many developmental processes, such as leaf venation pattern determination and filament elongation [35]. The MKK2-MPK10 cascade is involved in leaf venation architecture [193]. MEKK1 is necessary for external glutamate-mediated root architecture [194]. The ANP3-MKK6-MPK4 cascade plays an important role in male-specific meiotic cytokinesis [15]. As discussed above, the upstream regulators of many MAPK cascades involved in plant development are RLKs. Whether RLKs also perceive external signals and transduce them through these MAPK cascades without known upstream regulators to modulate plant development is worth further investigation. Moreover, the external signals transduced by these MAPK cascades and the so-far unknown RLKs will be important research topics in the near future.

RLKs play pivotal roles in mediating signaling pathways to regulate many important biological processes in plants. For example, some RLKs and small peptides mediate communications between the male and female during double fertilization, a crucial process for generating new generations of plants. FER, a Catharanthus roseus receptor-like kinase 1-like (CrRLK1L) RLK, is involved in female-mediated pollen tube reception [195]. ANXUR 1 (ANX1) and ANX2, two other CrRLK1L RLKs, are specifically expressed at the tip of pollen tube to regulate pollen cell wall integrity and pollen tube growth [196,197]. 
LURE1, a peptide secreted from the synergids, is perceived by POLLEN RECEPTOR LIKE KINASE 6 (PRK6), MALE DISCOVERER 1 (MDIS1), MDIS1-INTERACTING RECEPTOR LIKE KINASE 1 (MIK1) and MIK2 to guide pollen tube growth [198-200]. However, the downstream components of these RLK-mediated signaling pathways are still largely unknown. Whether MAPK cascades function downstream of these RLKs to regulate the processes is an intriguing question.

In fact, RLKs perceive extracellular signals and transmit the signals to intracellular transcription factors through a couple of pathways. Except BRI1- and BAK1-mediated brassinosteroid signaling that functions in a MAPK-independent manner [201], most known RLK-mediated signaling pathways recruit MAPK cascades. In plants, the MAPK protein family usually contains dozens of MAPKKK, MAPKK and MPK, implying that many MAPK cascades can be formed. Although other MAPK modules, such as the MKKK3/5-MKK4/5-MPK3/6 cascade regulating plant immunity downstream of PAMP receptors [163], have been identified, the YDA-MKK4/5-MPK3/6 module is likely the most common one that regulates plant development downstream of RLKs. This brings a question: Is YDA-MKK4/5-MPK3/6 a "RLK-specific" signaling cascade? One explanation is that YDA, MKK4/5, and MPK $3 / 6$ are the most thoroughly studied MAPKs in Arabidopsis, and the functions of many other MAPKs have not been revealed. For instance, there are 80 MAPKKKs existing in Arabidopsis, but only a few of them, like YDA, MEKK1, and CONSTITUTIVE TRIPLE RESPONSE 1 (CTR1), have been intensively investigated [87,88,202-207]. On the other hand, except having functions in RLK-mediated signaling pathways, MPK6 is also extensively involved in phytohormone-triggered signaling pathway $[71,182,208]$. Along with the deepening of research, it is possible that some novel MAPK modules functioning downstream of RLK-mediated signaling pathways to regulate plant development will be identified.

The same YDA-MKK4/5-MPK3/6 cascade is often recruited by various RLKs to regulate distinct developmental processes, such as embryo development [86], stomatal initiation [164], and inflorescence architecture [84]. Moreover, even the YDA-MKK4/5-MPK3/6 cascade is employed by ER to regulate both stomatal development and inflorescence architecture [84,164]. Therefore, how the signaling specificities of the MAPK cascade in distinct pathways is determined is another intriguing question. One possible explanation is that specific expression patterns of upstream ligands and RLKs can at least partially determine the MAPK cascade specificity, which then transduces the signal to distinct substrates and finally functions in different developmental processes. In addition, after different RLKs recognize the corresponding ligands, the recruited MAPKs may be phosphorylated differentially, resulting in distinct phosphorylation patterns that then possibly determine the specificity of the whole signaling pathway.

RLCKs, a group of RLKs without the extracellular domain, can interact directly with RLKs to regulate plant development and immunity [209]. For example, SSP interacts with ZAR1 to control the zygote asymmetric division [86]; CAST AWAY (CST) can interact with HAE to inhibit organ abscission [210]; RPM1-INDUCED PROTEIN KINASE (RIPK) and FER form a receptor complex that perceives RALF1 to inhibit root growth [211]; LOST IN POLLEN TUBE GUIDANCE 1/2 (LIP1/2) function as components of the receptor complex perceiving the LURE1 signal to mediate micropylar pollen tube guidance [212]; $M$-locus protein kinase (MLPK) transduces the self-incompatibility signal by interacting with the S-receptor kinase (SRK) in Brassica $[213,214]$. However, the current findings show that only SSP interacts with both ZAR1 and YDA to regulate the zygote asymmetric division [86], suggesting that RLCKs may bridge RLKs and MAPK cascades to regulate plant development. More RLCKs should be investigated to reveal their possible roles in RLK-MAPK-mediated signaling pathways.

Funding: This work was supported by the National Natural Science Foundation of China (31970339 and 31770312), and Fundamental Research Funds for the Central Universities (lzujbky-2019-ct04 and lzujbky-2020-kb05).

Conflicts of Interest: The authors declare no conflict of interest. 


\section{References}

1. Lewis, T.S.; Shapiro, P.S.; Ahn, N.G. Signal transduction through MAP kinase cascades. Adv. Cancer Res. 1998, 74, 49-139. [CrossRef] [PubMed]

2. Widmann, C.; Gibson, S.; Jarpe, M.B.; Johnson, G.L. Mitogen-activated protein kinase: Conservation of a three-kinase module from yeast to human. Physiol. Rev. 1999, 79, 143-180. [CrossRef]

3. Komis, G.; Šamajová, O.; Ovečka, M.; Šamaj, J. Cell and developmental biology of plant mitogen-activated protein kinases. Annu. Rev. Plant Biol. 2018, 69, 237-265. [CrossRef] [PubMed]

4. Çakır, B.; Kılıçkaya, O. Mitogen-activated protein kinase cascades in Vitis vinifera. Front. Plant Sci. 2015, 6, 556. [CrossRef] [PubMed]

5. Jonak, C.; Okresz, L.; Bogre, L.; Hirt, H. Complexity, cross talk and integration of plant MAP kinase signalling. Curr. Opin. Plant Biol. 2002, 5, 415-424. [CrossRef] [PubMed]

6. Colcombet, J.; Hirt, H. Arabidopsis MAPKs: A complex signalling network involved in multiple biological processes. Biochem. J. 2008, 413, 217-226. [CrossRef]

7. Group, M. Mitogen-activated protein kinase cascades in plants: A new nomenclature. Trends Plant Sci. 2002, 7, 301-308. [CrossRef]

8. Hord, C.L.; Sun, Y.J.; Pillitteri, L.J.; Torii, K.U.; Wang, H.; Zhang, S.; Ma, H. Regulation of Arabidopsis early anther development by the mitogen-activated protein kinases, MPK3 and MPK6, and the ERECTA and related receptor-like kinases. Mol. Plant 2008, 1, 645-658. [CrossRef]

9. Galletti, R.; Ferrari, S.; De Lorenzo, G. Arabidopsis MPK3 and MPK6 play different roles in basal and oligogalacturonide- or flagellin-induced resistance against Botrytis cinerea. Plant Physiol. 2011, 157, 804-814. [CrossRef]

10. Lee, H.; Jun, Y.S.; Cha, O.K.; Sheen, J. Mitogen-activated protein kinases MPK3 and MPK6 are required for stem cell maintenance in the Arabidopsis shoot apical meristem. Plant Cell Rep. 2019, 38, 311-319. [CrossRef]

11. Pedley, K.F.; Martin, G.B. Role of mitogen-activated protein kinases in plant immunity. Curr. Opin. Plant Biol. 2005, 8, 541-547. [CrossRef] [PubMed]

12. Zhang, A.; Zhang, J.; Ye, N.; Cao, J.; Tan, M.; Zhang, J.; Jiang, M. ZmMPK5 is required for the NADPH oxidase-mediated self-propagation of apoplastic $\mathrm{H}_{2} \mathrm{O}_{2}$ in brassinosteroid-induced antioxidant defence in leaves of maize. J. Exp. Bot. 2010, 61, 4399-4411. [CrossRef] [PubMed]

13. Gomi, K.; Ogawa, D.; Katou, S.; Kamada, H.; Nakajima, N.; Saji, H.; Soyano, T.; Sasabe, M.; Machida, Y.; Mitsuhara, I.; et al. A mitogen-activated protein kinase NtMPK4 activated by SIPKK is required for jasmonic acid signaling and involved in ozone tolerance via stomatal movement in tobacco. Plant Cell Physiol. 2005, 46, 1902-1914. [CrossRef] [PubMed]

14. Sasabe, M.; Kosetsu, K.; Hidaka, M.; Murase, A.; Machida, Y. Arabidopsis thaliana MAP65-1 and MAP65-2 function redundantly with MAP65-3/PLEIADE in cytokinesis downstream of MPK4. Plant Signal. Behav. 2011, 6, 743-747. [CrossRef] [PubMed]

15. Zeng, Q.; Chen, J.G.; Ellis, B.E. AtMPK4 is required for male-specific meiotic cytokinesis in Arabidopsis. Plant J. 2011, 67, 895-906. [CrossRef] [PubMed]

16. Yanagawa, Y.; Yoda, H.; Osaki, K.; Amano, Y.; Aono, M.; Seo, S.; Kuchitsu, K.; Mitsuhara, I. Mitogen-activated protein kinase 4-like carrying an MEY motif instead of a TXY motif is involved in ozone tolerance and regulation of stomatal closure in tobacco. J. Exp. Bot. 2016, 67, 3471-3479. [CrossRef] [PubMed]

17. Shi, J.; An, H.L.; Zhang, L.; Gao, Z.; Guo, X.Q. GhMPK7, a novel multiple stress-responsive cotton group C MAPK gene, has a role in broad spectrum disease resistance and plant development. Plant Mol. Biol. 2010, 74, 1-17. [CrossRef]

18. Takahashi, F.; Mizoguchi, T.; Yoshida, R.; Ichimura, K.; Shinozaki, K. Calmodulin-dependent activation of MAP kinase for ROS homeostasis in Arabidopsis. Mol. Cell 2011, 41, 649-660. [CrossRef]

19. Jammes, F.; Song, C.; Shin, D.; Munemasa, S.; Takeda, K.; Gu, D.; Cho, D.; Lee, S.; Giordo, R.; Sritubtim, S.; et al. MAP kinases MPK9 and MPK12 are preferentially expressed in guard cells and positively regulate ROS-mediated ABA signaling. Proc. Natl. Acad. Sci. USA 2009, 106, 20520-20525. [CrossRef]

20. Walia, A.; Lee, J.S.; Wasteneys, G.; Ellis, B. Arabidopsis mitogen-activated protein kinase MPK18 mediates cortical microtubule functions in plant cells. Plant J. 2009, 59, 565-575. [CrossRef] 
21. Salam, M.A.; Jammes, F.; Hossain, M.A.; Ye, W.; Nakamura, Y.; Mori, I.C.; Kwak, J.M.; Murata, Y. Two guard cell-preferential MAPKs, MPK9 and MPK12, regulate YEL signalling in Arabidopsis guard cells. Plant Biol. 2013, 15, 436-442. [CrossRef] [PubMed]

22. Xing, Y.; Jia, W.; Zhang, J. AtMEK1 mediates stress-induced gene expression of CAT1 catalase by triggering $\mathrm{H}_{2} \mathrm{O}_{2}$ production in Arabidopsis. J. Exp. Bot. 2007, 58, 2969-2981. [CrossRef] [PubMed]

23. Hadiarto, T.; Nanmori, T.; Matsuoka, D.; Iwasaki, T.; Sato, K.; Fukami, Y.; Azuma, T.; Yasuda, T. Activation of Arabidopsis MAPK kinase kinase (AtMEKK1) and induction of AtMEKK1-AtMEK1 pathway by wounding. Planta 2006, 223, 708-713. [CrossRef] [PubMed]

24. Li, Y.; Chang, Y.; Zhao, C.; Yang, H.; Ren, D. Expression of the inactive ZmMEK1 induces salicylic acid accumulation and salicylic acid-dependent leaf senescence. J. Integr. Plant Biol. 2016, 58, 724-736. [CrossRef]

25. Hwa, C.-M.; Yang, X.-C. The AtMKK3 pathway mediates ABA and salt signaling in Arabidopsis. Acta Physiol. Plant. 2007, 30, 277-286. [CrossRef]

26. Dóczi, R.; Brader, G.; Pettkó-Szandtner, A.; Rajh, I.; Djamei, A.; Pitzschke, A.; Teige, M.; Hirt, H. The Arabidopsis mitogen-activated protein kinase kinase MKK3 is upstream of group C mitogen-activated protein kinases and participates in pathogen signaling. Plant Cell 2007, 19, 3266-3279. [CrossRef] [PubMed]

27. Benhamman, R.; Bai, F.W.; Drory, S.B.; Loubert-Hudon, A.; Ellis, B.; Matton, D.P. The Arabidopsis mitogen-activated protein kinase kinase kinase 20 (MKKK20) acts upstream of MKK3 and MPK18 in two separate signaling pathways involved in root microtubule functions. Front. Plant Sci. 2017, 8, 1352. [CrossRef] [PubMed]

28. Zhao, C.; Nie, H.; Shen, Q.; Zhang, S.; Lukowitz, W.; Tang, D. EDR1 physically interacts with MKK4/MKK5 and negatively regulates a MAP kinase cascade to modulate plant innate immunity. PLoS Genet. 2014, 10, e1004389. [CrossRef]

29. Asai, T.; Tena, G.; Plotnikova, J.; Willmann, M.R.; Chiu, W.L.; Gomez-Gomez, L.; Boller, T.; Ausubel, F.M.; Sheen, J. MAP kinase signalling cascade in Arabidopsis innate immunity. Nature 2002, 415, 977-983. [CrossRef]

30. Zhang, J.; Gao, J.; Zhu, Z.; Song, Y.; Wang, X.; Wang, X.; Zhou, X. MKK4/MKK5-MPK1/MPK2 cascade mediates SA-activated leaf senescence via phosphorylation of NPR1 in Arabidopsis. Plant Mol. Biol. 2020, 102, 463-475. [CrossRef]

31. Wang, H.; Ngwenyama, N.; Liu, Y.; Walker, J.C.; Zhang, S. Stomatal development and patterning are regulated by environmentally responsive mitogen-activated protein kinases in Arabidopsis. Plant Cell 2007, 19, 63-73. [CrossRef]

32. Cho, S.K.; Larue, C.T.; Chevalier, D.; Wang, H.; Jinn, T.L.; Zhang, S.; Walker, J.C. Regulation of floral organ abscission in Arabidopsis thaliana. Proc. Natl. Acad. Sci. USA 2008, 105, 15629-15634. [CrossRef]

33. Zhang, M.; Wu, H.; Su, J.; Wang, H.; Zhu, Q.; Liu, Y.; Xu, J.; Lukowitz, W.; Zhang, S. Maternal control of embryogenesis by MPK6 and its upstream MKK4/MKK5 in Arabidopsis. Plant J. 2017, 92, 1005-1019. [CrossRef]

34. Heinrich, M.; Baldwin, I.T.; Wu, J. Two mitogen-activated protein kinase kinases, MKK1 and MEK2, are involved in wounding- and specialist lepidopteran herbivore Manduca sexta-induced responses in Nicotiana attenuata. J. Exp. Bot. 2011, 62, 4355-4365. [CrossRef] [PubMed]

35. Jia, W.; Li, B.; Li, S.; Liang, Y.; Wu, X.; Ma, M.; Wang, J.; Gao, J.; Cai, Y.; Zhang, Y.; et al. Mitogen-activated protein kinase cascade MKK7-MPK6 plays important roles in plant development and regulates shoot branching by phosphorylating PIN1 in Arabidopsis. PLoS Biol. 2016, 14, e1002550. [CrossRef] [PubMed]

36. Dóczi, R.; Hatzimasoura, E.; Bilooei, S.F.; Ahmad, Z.; Ditengou, F.A.; López-Juez, E.; Palme, K.; Bögre, L. The MKK7-MPK6 MAP kinase module is a regulator of meristem quiescence or active growth in Arabidopsis. Front. Plant Sci. 2019, 10, 202. [CrossRef] [PubMed]

37. Shen, L.; Zhuang, B.; Wu, Q.; Zhang, H.; Nie, J.; Jing, W.; Yang, L.; Zhang, W. Phosphatidic acid promotes the activation and plasma membrane localization of MKK7 and MKK9 in response to salt stress. Plant Sci. 2019, 287, 110190. [CrossRef]

38. Ichimura, K.; Casais, C.; Peck, S.C.; Shinozaki, K.; Shirasu, K. MEKK1 is required for MPK4 activation and regulates tissue-specific and temperature-dependent cell death in Arabidopsis. J. Biol. Chem. 2006, 281, 36969-36976. [CrossRef]

39. Pitzschke, A.; Djamei, A.; Bitton, F.; Hirt, H. A major role of the MEKK1-MKK1/2-MPK4 pathway in ROS signalling. Mol. Plant 2009, 2, 120-137. [CrossRef] 
40. Takahashi, Y.; Soyano, T.; Kosetsu, K.; Sasabe, M.; Machida, Y. HINKEL kinesin, ANP MAPKKKs and MKK6/ANQ MAPKK, which phosphorylates and activates MPK4 MAPK, constitute a pathway that is required for cytokinesis in Arabidopsis thaliana. Plant Cell Physiol. 2010, 51, 1766-1776. [CrossRef]

41. Musielak, T.J.; Bayer, M. YODA signalling in the early Arabidopsis embryo. Biochem. Soc. Trans. 2014, 42, 408-412. [CrossRef] [PubMed]

42. Abrash, E.; Anleu Gil, M.X.; Matos, J.L.; Bergmann, D.C. Conservation and divergence of YODA MAPKKK function in regulation of grass epidermal patterning. Development 2018, 145, dev165860. [CrossRef] [PubMed]

43. Samakovli, D.; Ticha, T.; Vavrdova, T.; Ovecka, M.; Luptovciak, I.; Zapletalova, V.; Kucharova, A.; Krenek, P.; Krasylenko, Y.; Margaritopoulou, T.; et al. YODA-HSP90 module regulates phosphorylation-dependent inactivation of SPEECHLESS to control stomatal development under acute heat stress in Arabidopsis. Mol. Plant 2020, 13, 612-633. [CrossRef]

44. Virk, N.; Li, D.; Tian, L.; Huang, L.; Hong, Y.; Li, X.; Zhang, Y.; Liu, B.; Zhang, H.; Song, F. Arabidopsis Raf-like mitogen-activated protein kinase kinase kinase gene Raf43 is required for tolerance to multiple abiotic stresses. PLoS ONE 2015, 10, e0133975. [CrossRef] [PubMed]

45. Wang, B.; Liu, G.; Zhang, J.; Li, Y.; Yang, H.; Ren, D. The RAF-like mitogen-activated protein kinase kinase kinases RAF22 and RAF28 are required for the regulation of embryogenesis in Arabidopsis. Plant J. 2018, 96, 734-747. [CrossRef]

46. Champion, A.; Picaud, A.; Henry, Y. Reassessing the MAP3K and MAP4K relationships. Trends Plant Sci. 2004, 9, 123-129. [CrossRef]

47. Duerr, B.; Gawienowski, M.; Ropp, T.; Jacobs, T. MsERK1: A mitogen-activated protein kinase from a flowering plant. Plant Cell 1993, 5, 87-96. [CrossRef] [PubMed]

48. Suarez-Rodriguez, M.C.; Adams-Phillips, L.; Liu, Y.; Wang, H.; Su, S.H.; Jester, P.J.; Zhang, S.; Bent, A.F.; Krysan, P.J. MEKK1 is required for flg22-induced MPK4 activation in Arabidopsis plants. Plant Physiol. 2007, 143, 661-669. [CrossRef]

49. Chinchilla, D.; Zipfel, C.; Robatzek, S.; Kemmerling, B.; Nurnberger, T.; Jones, J.D.; Felix, G.; Boller, T. A flagellin-induced complex of the receptor FLS2 and BAK1 initiates plant defence. Nature 2007, 448, 497-500. [CrossRef]

50. Romeis, T.; Piedras, P.; Zhang, S.; Klessig, D.F.; Hirt, H.; Jones, J.D. Rapid Avr9- and Cf-9-dependent activation of MAP kinases in tobacco cell cultures and leaves: Convergence of resistance gene, elicitor, wound, and salicylate responses. Plant Cell 1999, 11, 273-287. [CrossRef]

51. Ekengren, S.K.; Liu, Y.; Schiff, M.; Dinesh-Kumar, S.P.; Martin, G.B. Two MAPK cascades, NPR1, and TGA transcription factors play a role in Pto-mediated disease resistance in tomato. Plant J. 2003, 36, 905-917. [CrossRef]

52. Teige, M.; Scheikl, E.; Eulgem, T.; Doczi, F.; Ichimura, K.; Shinozaki, K.; Dangl, J.L.; Hirt, H. The MKK2 pathway mediates cold and salt stress signaling in Arabidopsis. Mol. Cell 2004, 15, 141-152. [CrossRef]

53. Kim, T.W.; Michniewicz, M.; Bergmann, D.C.; Wang, Z.Y. Brassinosteroid regulates stomatal development by GSK3-mediated inhibition of a MAPK pathway. Nature 2012, 482, 419-422. [CrossRef] [PubMed]

54. Meng, X.; Zhou, J.; Tang, J.; Li, B.; de Oliveira, M.V.V.; Chai, J.; He, P.; Shan, L. Ligand-induced receptor-like kinase complex regulates floral organ abscission in Arabidopsis. Cell Rep. 2016, 14, 1330-1338. [CrossRef]

55. Li, H.; Cai, Z.; Wang, X.; Li, M.; Cui, Y.; Cui, N.; Yang, F.; Zhu, M.; Zhao, J.; Du, W.; et al. SERK receptor-like kinases control division patterns of vascular precursors and ground tissue stem cells during embryo development in Arabidopsis. Mol. Plant 2019, 12, 984-1002. [CrossRef]

56. Zhu, Q.; Shao, Y.; Ge, S.; Zhang, M.; Zhang, T.; Hu, X.; Liu, Y.; Walker, J.; Zhang, S.; Xu, J. A MAPK cascade downstream of IDA-HAE/HSL2 ligand-receptor pair in lateral root emergence. Nat. Plants 2019, 5, 414-423. [CrossRef]

57. Bush, S.M.; Krysan, P.J. Mutational evidence that the Arabidopsis MAP kinase MPK6 is involved in anther, inflorescence, and embryo development. J. Exp. Bot. 2007, 58, 2181-2191. [CrossRef]

58. Müller, J.; Beck, M.; Mettbach, U.; Komis, G.; Hause, G.; Menzel, D.; Samaj, J. Arabidopsis MPK6 is involved in cell division plane control during early root development, and localizes to the pre-prophase band, phragmoplast, trans-Golgi network and plasma membrane. Plant J. 2010, 61, 234-248. [CrossRef]

59. Guan, Y.; Lu, J.; Xu, J.; McClure, B.; Zhang, S. Two mitogen-activated protein kinases, MPK3 and MPK6, are required for funicular guidance of pollen tubes in Arabidopsis. Plant Physiol. 2014, 165, 528-533. [CrossRef] 
60. Smékalová, V.; Luptovčiak, I.; Komis, G.; Šamajová, O.; Ovečka, M.; Doskočilová, A.; Takáč, T.; Vadovič, P.; Novák, O.; Pechan, T.; et al. Involvement of YODA and mitogen activated protein kinase 6 in Arabidopsis post-embryogenic root development through auxin up-regulation and cell division plane orientation. New Phytol. 2014, 203, 1175-1193. [CrossRef] [PubMed]

61. Coronado, M.J.; González-Melendi, P.; Seguí, J.M.; Ramírez, C.; Bárány, I.; Testillano, P.S.; Risueño, M.C. MAPKs entry into the nucleus at specific interchromatin domains in plant differentiation and proliferation processes. J. Struct. Biol. 2002, 140, 200-213. [CrossRef]

62. Cheong, Y.H.; Moon, B.C.; Kim, J.K.; Kim, C.Y.; Kim, M.C.; Kim, I.H.; Park, C.Y.; Kim, J.C.; Park, B.O.; Koo, S.C.; et al. BWMK1, a rice mitogen-activated protein kinase, locates in the nucleus and mediates pathogenesis-related gene expression by activation of a transcription factor. Plant Physiol. 2003, 132, 1961-1972. [CrossRef] [PubMed]

63. Zadi, I.; Ebel, C.; Touzri, M.; Herzog, E.; Evrard, J.L.; Schmit, A.C.; Masmoudi, K.; Hanin, M. TMKP1 is a novel wheat stress responsive MAP kinase phosphatase localized in the nucleus. Plant Mol. Biol. 2010, 73, 325-338. [CrossRef] [PubMed]

64. Ahlfors, R.; Macioszek, V.; Rudd, J.; Brosche, M.; Schlichting, R.; Scheel, D.; Kangasjarvi, J. Stress hormone-independent activation and nuclear translocation of mitogen-activated protein kinases in Arabidopsis thaliana during ozone exposure. Plant J. 2004, 40, 512-522. [CrossRef]

65. Ligterink, W.; Kroj, T.; zur Nieden, U.; Hirt, H.; Scheel, D. Receptor-mediated activation of a MAP kinase in pathogen defense of plants. Science 1997, 276, 2054-2057. [CrossRef]

66. Cargnello, M.; Roux, P.P. Activation and function of the MAPKs and their substrates, the MAPK-activated protein kinases. Microbiol. Mol. Biol. Rev. 2011, 75, 50-83. [CrossRef]

67. Beck, M.; Komis, G.; Müller, J.; Menzel, D.; Šamaj, J. Arabidopsis homologs of nucleus- and phragmoplast-localized kinase 2 and 3 and mitogen-activated protein kinase 4 are essential for microtubule organization. Plant Cell 2010, 22, 755-771. [CrossRef]

68. Khokon, M.A.; Salam, M.A.; Jammes, F.; Ye, W.; Hossain, M.A.; Uraji, M.; Nakamura, Y.; Mori, I.C.; Kwak, J.M.; Murata, Y. Two guard cell mitogen-activated protein kinases, MPK9 and MPK12, function in methyl jasmonate-induced stomatal closure in Arabidopsis thaliana. Plant Biol. 2015, 17, 946-952. [CrossRef]

69. Montillet, J.L.; Leonhardt, N.; Mondy, S.; Tranchimand, S.; Rumeau, D.; Boudsocq, M.; Garcia, A.V.; Douki, T.; Bigeard, J.; Lauriere, C.; et al. An abscisic acid-independent oxylipin pathway controls stomatal closure and immune defense in Arabidopsis. PLoS Biol. 2013, 11, e1001513. [CrossRef]

70. Novikova, G.V.; Moshkov, I.E.; Smith, A.R.; Hall, M.A. The effect of ethylene on MAPKinase-like activity in Arabidopsis thaliana. FEBS Lett. 2000, 474, 29-32. [CrossRef]

71. Xing, Y.; Jia, W.; Zhang, J. AtMKK1 and AtMPK6 are involved in abscisic acid and sugar signaling in Arabidopsis seed germination. Plant Mol. Biol. 2009, 70, 725-736. [CrossRef] [PubMed]

72. Yue, H.; Nie, S.; Xing, D. Over-expression of Arabidopsis Bax inhibitor-1 delays methyl jasmonate-induced leaf senescence by suppressing the activation of MAP kinase 6. J. Exp. Bot. 2012, 63, 4463-4474. [CrossRef]

73. Neill, S.; Barros, R.; Bright, J.; Desikan, R.; Hancock, J.; Harrison, J.; Morris, P.; Ribeiro, D.; Wilson, I. Nitric oxide, stomatal closure, and abiotic stress. J. Exp. Bot. 2008, 59, 165-176. [CrossRef]

74. van der Geer, P.; Hunter, T.; Lindberg, R.A. Receptor protein-tyrosine kinases and their signal transduction pathways. Annu. Rev. Cell Biol. 1994, 10, 251-337. [CrossRef] [PubMed]

75. Zwick, E.; Bange, J.; Ullrich, A. Receptor tyrosine kinase signalling as a target for cancer intervention strategies. Endocr. Relat. Cancer 2001, 8, 161-173. [CrossRef]

76. Walker, J.C.; Zhang, R. Relationship of a putative receptor protein kinase from maize to the $S$-locus glycoproteins of Brassica. Nature 1990, 345, 743-746. [CrossRef] [PubMed]

77. Goring, D.R.; Glavin, T.L.; Schafer, U.; Rothstein, S.J. An S receptor kinase gene in self-compatible Brassica napus has a 1-bp deletion. Plant Cell 1993, 5, 531-539. [CrossRef]

78. Walker, J.C. Receptor-like protein kinase genes of Arabidopsis thaliana. Plant J. 1993, 3, 451-456. [CrossRef]

79. Shiu, S.H.; Bleecker, A.B. Receptor-like kinases from Arabidopsis form a monophyletic gene family related to animal receptor kinases. Proc. Natl. Acad. Sci. USA 2001, 98, 10763-10768. [CrossRef]

80. Becraft, P.W. Receptor kinase signaling in plant development. Annu. Rev. Cell Dev. Biol. 2002, 18, 163-192. [CrossRef]

81. Dievart, A.; Gottin, C.; Périn, C.; Ranwez, V.; Chantret, N. Origin and diversity of plant receptor-like kinases. Annu. Rev. Plant Biol. 2020, 71, 131-156. [CrossRef] [PubMed] 
82. Jose, J.; Ghantasala, S.; Roy Choudhury, S. Arabidopsis transmembrane receptor-like kinases (RLKs): A bridge between extracellular signal and intracellular regulatory machinery. Int. J. Mol. Sci. 2020, 21, 4000. [CrossRef] [PubMed]

83. Gou, X.; He, K.; Yang, H.; Yuan, T.; Lin, H.; Clouse, S.D.; Li, J. Genome-wide cloning and sequence analysis of leucine-rich repeat receptor-like protein kinase genes in Arabidopsis thaliana. BMC Genom. 2010, 11, 19. [CrossRef]

84. Meng, X.; Wang, H.; He, Y.; Liu, Y.; Walker, J.C.; Torii, K.U.; Zhang, S. A MAPK cascade downstream of ERECTA receptor-like protein kinase regulates Arabidopsis inflorescence architecture by promoting localized cell proliferation. Plant Cell 2012, 24, 4948-4960. [CrossRef] [PubMed]

85. Lu, D.; He, P.; Shan, L. Bacterial effectors target BAK1-associated receptor complexes: One stone two birds. Commun. Integr. Biol. 2010, 3, 80-83. [CrossRef]

86. Yuan, G.L.; Li, H.J.; Yang, W.C. The integration of G $\beta$ and MAPK signaling cascade in zygote development. Sci. Rep. 2017, 7, 1-11. [CrossRef]

87. Lukowitz, W.; Roeder, A.; Parmenter, D.; Somerville, C. A MAPKK kinase gene regulates extra-embryonic cell fate in Arabidopsis. Cell 2004, 116, 109-119. [CrossRef]

88. Bergmann, D.C.; Lukowitz, W.; Somerville, C.R. Stomatal development and pattern controlled by a MAPKK kinase. Science 2004, 304, 1494-1497. [CrossRef]

89. Haecker, A.; Gross-Hardt, R.; Geiges, B.; Sarkar, A.; Breuninger, H.; Herrmann, M.; Laux, T. Expression dynamics of WOX genes mark cell fate decisions during early embryonic patterning in Arabidopsis thaliana. Development 2004, 131, 657-668. [CrossRef]

90. Breuninger, H.; Rikirsch, E.; Hermann, M.; Ueda, M.; Laux, T. Differential expression of WOX genes mediates apical-basal axis formation in the Arabidopsis embryo. Dev. Cell 2008, 14, 867-876. [CrossRef]

91. Ueda, M.; Zhang, Z.; Laux, T. Transcriptional activation of Arabidopsis axis patterning genes WOX8/9 links zygote polarity to embryo development. Dev. Cell 2011, 20, 264-270. [CrossRef]

92. Ueda, M.; Aichinger, E.; Gong, W.; Groot, E.; Verstraeten, I.; Vu, L.D.; De Smet, I.; Higashiyama, T.; Umeda, M.; Laux, T. Transcriptional integration of paternal and maternal factors in the Arabidopsis zygote. Genes Dev. 2017, 31, 617-627. [CrossRef] [PubMed]

93. Bayer, M.; Nawy, T.; Giglione, C.; Galli, M.; Meinnel, T.; Lukowitz, W. Paternal control of embryonic patterning in Arabidopsis thaliana. Science 2009, 323, 1485-1488. [CrossRef] [PubMed]

94. Yu, T.Y.; Shi, D.Q.; Jia, P.F.; Tang, J.; Li, H.J.; Liu, J.; Yang, W.C. The Arabidopsis receptor kinase ZAR1 is required for zygote asymmetric division and its daughter cell fate. PLoS Genet. 2016, 12, e1005933. [CrossRef]

95. Costa, L.M.; Marshall, E.; Tesfaye, M.; Silverstein, K.A.; Mori, M.; Umetsu, Y.; Otterbach, S.L.; Papareddy, R.; Dickinson, H.G.; Boutiller, K.; et al. Central cell-derived peptides regulate early embryo patterning in flowering plants. Science 2014, 344, 168-172. [CrossRef] [PubMed]

96. Li, J.; Wen, J.Q.; Lease, K.A.; Doke, J.T.; Tax, F.E.; Walker, J.C. BAK1, an Arabidopsis LRR receptor-like protein kinase, interacts with BRI1 and modulates brassinosteroid signaling. Cell 2002, 110, 213-222. [CrossRef]

97. Nam, K.H.; Li, J. BRI1/BAK1, a receptor kinase pair mediating brassinosteroid signaling. Cell 2002, 110, 203-212. [CrossRef]

98. Ladwig, F.; Dahlke, R.I.; Stuhrwohldt, N.; Hartmann, J.; Harter, K.; Sauter, M. Phytosulfokine regulates growth in Arabidopsis through a response module at the plasma membrane that includes CYCLIC NUCLEOTIDE-GATED CHANNEL17, $\mathrm{H}^{+}$-ATPase, and BAK1. Plant Cell 2015, 27, 1718-1729. [CrossRef]

99. Meng, X.; Chen, X.; Mang, H.; Liu, C.; Yu, X.; Gao, X.; Torii, K.; He, P.; Shan, L. Differential function of Arabidopsis SERK family receptor-like kinases in stomatal patterning. Curr. Biol. 2015, 25, 2361-2372. [CrossRef]

100. Ou, Y.; Lu, X.T.; Zi, Q.N.; Xun, Q.Q.; Zhang, J.J.; Wu, Y.J.; Shi, H.Y.; Wei, Z.Y.; Zhao, B.L.; Zhang, X.Y.; et al. RGF1 INSENSITIVE 1 to 5, a group of LRR receptor-like kinases, are essential for the perception of root meristem growth factor 1 in Arabidopsis thaliana. Cell Res. 2016, 26, 686-698. [CrossRef]

101. Santiago, J.; Brandt, B.; Wildhagen, M.; Hohmann, U.; Hothorn, L.A.; Butenko, M.A.; Hothorn, M. Mechanistic insight into a peptide hormone signaling complex mediating floral organ abscission. Elife 2016, 5, e15075. [CrossRef] [PubMed]

102. Song, W.; Liu, L.; Wang, J.; Wu, Z.; Zhang, H.; Tang, J.; Lin, G.; Wang, Y.; Wen, X.; Li, W.; et al. Signature motif-guided identification of receptors for peptide hormones essential for root meristem growth. Cell Res. 2016, 26, 674-685. [CrossRef] [PubMed] 
103. Zhang, H.; Lin, X.; Han, Z.; Wang, J.; Qu, L.J.; Chai, J. SERK family receptor-like kinases function as co-receptors with PXY for plant vascular development. Mol. Plant 2016, 9, 1406-1414. [CrossRef] [PubMed]

104. Li, Z.; Wang, Y.; Huang, J.; Ahsan, N.; Biener, G.; Paprocki, J.; Thelen, J.J.; Raicu, V.; Zhao, D. Two SERK receptor-like kinases interact with EMS1 to control anther cell fate determination. Plant Physiol. 2017, 173, 326-337. [CrossRef] [PubMed]

105. Qian, P.; Song, W.; Yokoo, T.; Minobe, A.; Wang, G.; Ishida, T.; Sawa, S.; Chai, J.; Kakimoto, T. The CLE9/10 secretory peptide regulates stomatal and vascular development through distinct receptors. Nat. Plants 2018, 4, 1071-1081. [CrossRef] [PubMed]

106. Gou, X.P.; Li, J. Paired receptor and coreceptor kinases perceive extracellular signals to control plant development. Plant Physiol. 2020, 182, 1667-1681. [CrossRef] [PubMed]

107. Tsuwamoto, R.; Fukuoka, H.; Takahata, Y. GASSHO1 and GASSHO2 encoding a putative leucine-rich repeat transmembrane-type receptor kinase are essential for the normal development of the epidermal surface in Arabidopsis embryos. Plant J. 2008, 54, 30-42. [CrossRef] [PubMed]

108. Doll, N.M.; Royek, S.; Fujita, S.; Okuda, S.; Chamot, S.; Stintzi, A.; Widiez, T.; Hothorn, M.; Schaller, A.; Geldner, N.; et al. A two-way molecular dialogue between embryo and endosperm is required for seed development. Science 2020, 367, 431-435. [CrossRef]

109. Fiume, E.; Guyon, V.; Remoué, C.; Magnani, E.; Miquel, M.; Grain, D.; Lepiniec, L. TWS1, a novel small protein, regulates various aspects of seed and plant development. Plant Physiol. 2016, 172, 1732-1745. [CrossRef]

110. Xing, Q.; Creff, A.; Waters, A.; Tanaka, H.; Goodrich, J.; Ingram, G.C. ZHOUPI controls embryonic cuticle formation via a signalling pathway involving the subtilisin protease ABNORMAL LEAF-SHAPE1 and the receptor kinases GASSHO1 and GASSHO2. Development 2013, 140, 770-779. [CrossRef]

111. Yang, S.; Johnston, N.; Talideh, E.; Mitchell, S.; Jeffree, C.; Goodrich, J.; Ingram, G. The endosperm-specific ZHOUPI gene of Arabidopsis thaliana regulates endosperm breakdown and embryonic epidermal development. Development 2008, 135, 3501-3509. [CrossRef]

112. López-Bucio, J.S.; Dubrovsky, J.G.; Raya-González, J.; Ugartechea-Chirino, Y.; López-Bucio, J.; de Luna-Valdez, L.A.; Ramos-Vega, M.; Leon, P.; Guevara-Garcia, A.A. Arabidopsis thaliana mitogen-activated protein kinase 6 is involved in seed formation and modulation of primary and lateral root development. J. Exp. Bot. 2014, 65, 169-183. [CrossRef]

113. Creff, A.; Brocard, L.; Joubès, J.; Taconnat, L.; Doll, N.M.; Marsollier, A.C.; Pascal, S.; Galletti, R.; Boeuf, S.; Moussu, S.; et al. A stress-response-related inter-compartmental signalling pathway regulates embryonic cuticle integrity in Arabidopsis. PLoS Genet. 2019, 15, e1007847. [CrossRef] [PubMed]

114. Doblas, V.G.; Smakowska-Luzan, E.; Fujita, S.; Alassimone, J.; Barberon, M.; Madalinski, M.; Belkhadir, Y.; Geldner, N. Root diffusion barrier control by a vasculature-derived peptide binding to the SGN3 receptor. Science 2017, 355, 280-284. [CrossRef]

115. Nakayama, T.; Shinohara, H.; Tanaka, M.; Baba, K.; Ogawa-Ohnishi, M.; Matsubayashi, Y. A peptide hormone required for Casparian strip diffusion barrier formation in Arabidopsis roots. Science 2017, 355, $284-286$. [CrossRef] [PubMed]

116. Okuda, S.; Fujita, S.; Moretti, A.; Hohmann, U.; Doblas, V.G.; Ma, Y.; Pfister, A.; Brandt, B.; Geldner, N.; Hothorn, M. Molecular mechanism for the recognition of sequence-divergent CIF peptides by the plant receptor kinases GSO1/SGN3 and GSO2. Proc. Natl. Acad. Sci. USA 2020, 117, 2693-2703. [CrossRef] [PubMed]

117. Schiefthaler, U.; Balasubramanian, S.; Sieber, P.; Chevalier, D.; Wisman, E.; Schneitz, K. Molecular analysis of NOZZLE, a gene involved in pattern formation and early sporogenesis during sex organ development in Arabidopsis thaliana. Proc. Natl. Acad. Sci. USA 1999, 96, 11664-11669. [CrossRef]

118. Yang, W.; Ye, D.; Xu, J.; Sundaresan, V. The SPOROCYTELESS gene of Arabidopsis is required for initiation of sporogenesis and encodes a novel nuclear protein. Genes Dev. 1999, 13, 2108-2117. [CrossRef]

119. Ito, T.; Wellmer, F.; Yu, H.; Das, P.; Ito, N.; Alves-Ferreira, M.; Riechmann, J.L.; Meyerowitz, E.M. The homeotic protein AGAMOUS controls microsporogenesis by regulation of SPOROCYTELESS. Nature 2004, 430, 356-360. [CrossRef]

120. Zhao, F.; Zheng, Y.F.; Zeng, T.; Sun, R.; Yang, J.Y.; Li, Y.; Ren, D.T.; Ma, H.; Xu, Z.H.; Bai, S.N. Phosphorylation of SPOROCYTELESS/NOZZLE by the MPK3/6 kinase is required for anther development. Plant Physiol. 2017, 173, 2265-2277. [CrossRef] 
121. Shpak, E.D.; Berthiaume, C.T.; Hill, E.J.; Torii, K.U. Synergistic interaction of three ERECTA-family receptor-like kinases controls Arabidopsis organ growth and flower development by promoting cell proliferation. Development 2004, 131, 1491-1501. [CrossRef] [PubMed]

122. Canales, C.; Bhatt, A.M.; Scott, R.; Dickinson, H. EXS, a putative LRR receptor kinase, regulates male germline cell number and tapetal identity and promotes seed development in Arabidopsis. Curr. Biol. 2002, 12, 1718-1727. [CrossRef]

123. Zhao, D.Z.; Wang, G.F.; Speal, B.; Ma, H. The EXCESS MICROSPOROCYTES1 gene encodes a putative leucine-rich repeat receptor protein kinase that controls somatic and reproductive cell fates in the Arabidopsis anther. Gene Dev. 2002, 16, 2021-2031. [CrossRef]

124. Jia, G.; Liu, X.; Owen, H.; Zhao, D. Signaling of cell fate determination by the TPD1 small protein and EMS1 receptor kinase. Proc. Natl. Acad. Sci. USA 2008, 105, 2220-2225. [CrossRef]

125. Albrecht, C.; Russinova, E.; Hecht, V.; Baaijens, E.; de Vries, S. The Arabidopsis thaliana SOMATIC EMBRYOGENESIS RECEPTOR-LIKE KINASES1 and 2 control male sporogenesis. Plant Cell 2005, 17, 3337-3349. [CrossRef]

126. Colcombet, J.; Boisson-Dernier, A.; Ros-Palau, R.; Vera, C.E.; Schroeder, J.I. Arabidopsis SOMATIC EMBRYOGENESIS RECEPTOR KINASES1 and 2 are essential for tapetum development and microspore maturation. Plant Cell 2005, 17, 3350-3361. [CrossRef]

127. Hord, C.L.H.; Chen, C.B.; DeYoung, B.J.; Clark, S.E.; Ma, H. The BAM1/BAM2 receptor-like kinases are important regulators of Arabidopsis early anther development. Plant Cell 2006, 18, 1667-1680. [CrossRef]

128. Mizuno, S.; Osakabe, Y.; Maruyama, K.; Ito, T.; Osakabe, K.; Sato, T.; Shinozaki, K.; Yamaguchi-Shinozaki, K. Receptor-like protein kinase 2 (RPK 2) is a novel factor controlling anther development in Arabidopsis thaliana. Plant J. 2007, 50, 751-766. [CrossRef]

129. Cui, Y.W.; Hu, C.; Zhu, Y.F.; Cheng, K.L.; Li, X.N.; Wei, Z.Y.; Xue, L.; Lin, F.; Shi, H.Y.; Yi, J.; et al. CIK receptor kinases determine cell fate specification during early anther development in Arabidopsis. Plant Cell 2018, 30, 2383-2401. [CrossRef]

130. McKim, S.M.; Stenvik, G.E.; Butenko, M.A.; Kristiansen, W.; Cho, S.K.; Hepworth, S.R.; Aalen, R.B.; Haughn, G.W. The BLADE-ON-PETIOLE genes are essential for abscission zone formation in Arabidopsis. Development 2008, 135, 1537-1546. [CrossRef]

131. Stenvik, G.E.; Tandstad, N.M.; Guo, Y.; Shi, C.L.; Kristiansen, W.; Holmgren, A.; Clark, S.E.; Aalen, R.B.; Butenko, M.A. The EPIP peptide of INFLORESCENCE DEFICIENT IN ABSCISSION is sufficient to induce abscission in arabidopsis through the receptor-like kinases HAESA and HAESA-LIKE2. Plant Cell 2008, 20, 1805-1817. [CrossRef] [PubMed]

132. Butenko, M.A.; Patterson, S.E.; Grini, P.E.; Stenvik, G.E.; Amundsen, S.S.; Mandal, A.; Aalen, R.B. INFLORESCENCE DEFICIENT IN ABSCISSION controls floral organ abscission in Arabidopsis and identifies a novel family of putative ligands in plants. Plant Cell 2003, 15, 2296-2307. [CrossRef] [PubMed]

133. Stenvik, G.E.; Butenko, M.A.; Urbanowicz, B.R.; Rose, J.K.; Aalen, R.B. Overexpression of INFLORESCENCE DEFICIENT IN ABSCISSION activates cell separation in vestigial abscission zones in Arabidopsis. Plant Cell 2006, 18, 1467-1476. [CrossRef] [PubMed]

134. Patharkar, O.R.; Walker, J.C. Floral organ abscission is regulated by a positive feedback loop. Proc. Natl. Acad. Sci. USA 2015, 112, 2906-2911. [CrossRef] [PubMed]

135. Patharkar, O.R.; Walker, J.C. Core mechanisms regulating developmentally timed and environmentally triggered abscission. Plant Physiol. 2016, 172, 510-520. [CrossRef]

136. Leslie, M.E.; Lewis, M.W.; Youn, J.Y.; Daniels, M.J.; Liljegren, S.J. The EVERSHED receptor-like kinase modulates floral organ shedding in Arabidopsis. Development 2010, 137, 467-476. [CrossRef]

137. Shi, C.L.; Stenvik, G.E.; Vie, A.K.; Bones, A.M.; Pautot, V.; Proveniers, M.; Aalen, R.B.; Butenko, M.A. Arabidopsis class I KNOTTED-like homeobox proteins act downstream in the IDA-HAE/HSL2 floral abscission signaling pathway. Plant Cell 2011, 23, 2553-2567. [CrossRef]

138. Reichardt, S.; Piepho, H.P.; Stintzi, A.; Schaller, A. Peptide signaling for drought-induced tomato flower drop. Science 2020, 367, 1482-1485. [CrossRef]

139. Matsubayashi, Y.; Sakagami, Y. Phytosulfokine, sulfated peptides that induce the proliferation of single mesophyll cells of Asparagus officinalis L. Proc. Natl. Acad. Sci. USA 1996, 93, 7623-7627. [CrossRef]

140. Sauter, M. Phytosulfokine peptide signalling. J. Exp. Bot. 2015, 66, 5160-5168. [CrossRef] 
141. Stuhrwohldt, N.; Dahlke, R.I.; Kutschmar, A.; Peng, X.; Sun, M.X.; Sauter, M. Phytosulfokine peptide signaling controls pollen tube growth and funicular pollen tube guidance in Arabidopsis thaliana. Physiol. Plant 2015, 153, 643-653. [CrossRef] [PubMed]

142. Dong, J.; MacAlister, C.A.; Bergmann, D.C. BASL controls asymmetric cell division in Arabidopsis. Cell 2009, 137, 1320-1330. [CrossRef] [PubMed]

143. Geisler, M.; Nadeau, J.; Sack, F.D. Oriented asymmetric divisions that generate the stomatal spacing pattern in Arabidopsis are disrupted by the too many mouths mutation. Plant Cell 2000, 12, 2075-2086. [CrossRef] [PubMed]

144. Pillitteri, L.J.; Torii, K.U. Mechanisms of stomatal development. Annu. Rev. Plant Biol. 2012, 63, 591-614. [CrossRef]

145. Zhao, L.; Sack, F.D. Ultrastructure of stomatal development in Arabidopsis (Brassicaceae) leaves. Am. J. Bot. 1999, 86, 929-939. [CrossRef]

146. Hara, K.; Kajita, R.; Torii, K.U.; Bergmann, D.C.; Kakimoto, T. The secretory peptide gene EPF1 enforces the stomatal one-cell-spacing rule. Genes Dev. 2007, 21, 1720-1725. [CrossRef]

147. Hunt, L.; Gray, J.E. The signaling peptide EPF2 controls asymmetric cell divisions during stomatal development. Curr. Biol. 2009, 19, 864-869. [CrossRef]

148. Hara, K.; Yokoo, T.; Kajita, R.; Onishi, T.; Yahata, S.; Peterson, K.M.; Torii, K.U.; Kakimoto, T. Epidermal cell density is autoregulated via a secretory peptide, EPIDERMAL PATTERNING FACTOR 2 in Arabidopsis leaves. Plant Cell Physiol. 2009, 50, 1019-1031. [CrossRef]

149. Sugano, S.S.; Shimada, T.; Imai, Y.; Okawa, K.; Tamai, A.; Mori, M.; Hara-Nishimura, I. Stomagen positively regulates stomatal density in Arabidopsis. Nature 2010, 463, 241-244. [CrossRef]

150. Hunt, L.; Bailey, K.J.; Gray, J.E. The signalling peptide EPFL9 is a positive regulator of stomatal development. New Phytol. 2010, 186, 609-614. [CrossRef]

151. Kondo, T.; Kajita, R.; Miyazaki, A.; Hokoyama, M.; Nakamura-Miura, T.; Mizuno, S.; Masuda, Y.; Irie, K.; Tanaka, Y.; Takada, S.; et al. Stomatal density is controlled by a mesophyll-derived signaling molecule. Plant Cell Physiol. 2010, 51, 1-8. [CrossRef]

152. Lee, J.S.; Hnilova, M.; Maes, M.; Lin, Y.C.L.; Putarjunan, A.; Han, S.K.; Avila, J.; Torii, K.U. Competitive binding of antagonistic peptides fine-tunes stomatal patterning. Nature 2015, 522, 435-443. [CrossRef] [PubMed]

153. Lee, J.S.; Kuroha, T.; Hnilova, M.; Khatayevich, D.; Kanaoka, M.M.; McAbee, J.M.; Sarikaya, M.; Tamerler, C.; Torii, K.U. Direct interaction of ligand-receptor pairs specifying stomatal patterning. Genes Dev. 2012, 26, 126-136. [CrossRef]

154. Shpak, E.D. Diverse roles of ERECTA family genes in plant development. J. Integr. Plant Biol. 2013, 55, 1238-1250. [CrossRef] [PubMed]

155. Shpak, E.D.; McAbee, J.M.; Pillitteri, L.J.; Torii, K.U. Stomatal patterning and differentiation by synergistic interactions of receptor kinases. Science 2005, 309, 290-293. [CrossRef]

156. Yang, M.; Sack, F.D. The too many mouths and four lips mutations affect stomatal production in Arabidopsis. Plant Cell 1995, 7, 2227-2239. [CrossRef] [PubMed]

157. Nadeau, J.A.; Sack, F.D. Control of stomatal distribution on the Arabidopsis leaf surface. Science 2002, 296, 1697-1700. [CrossRef]

158. Serna, L. Plant biology—Good neighbours. Nature 2004, 430, 302-304. [CrossRef]

159. Sack, F.D. YODA would be proud: Valves for land plants. Science 2004, 304, 1461-1462. [CrossRef]

160. Lampard, G.R.; Lukowitz, W.; Ellis, B.E.; Bergmann, D.C. Novel and expanded roles for MAPK signaling in Arabidopsis stomatal cell fate revealed by cell type-specific manipulations. Plant Cell 2009, 21, 3506-3517. [CrossRef]

161. Li, J.; Nam, K.H.; Vafeados, D.; Chory, J. BIN2, a new brassinosteroid-insensitive locus in Arabidopsis. Plant Physiol. 2001, 127, 14-22. [CrossRef] [PubMed]

162. Khan, M.; Rozhon, W.; Bigeard, J.; Pflieger, D.; Husar, S.; Pitzschke, A.; Teige, M.; Jonak, C.; Hirt, H.; Poppenberger, B. Brassinosteroid-regulated GSK3/Shaggy-like kinases phosphorylate mitogen-activated protein (MAP) kinase kinases, which control stomata development in Arabidopsis thaliana. J. Biol. Chem. 2013, 288, 7519-7527. [CrossRef] [PubMed] 
163. Sun, T.; Nitta, Y.; Zhang, Q.; Wu, D.; Tian, H.; Lee, J.S.; Zhang, Y. Antagonistic interactions between two MAP kinase cascades in plant development and immune signaling. EMBO Rep. 2018, 19, e45324. [CrossRef] [PubMed]

164. Lampard, G.R.; Macalister, C.A.; Bergmann, D.C. Arabidopsis stomatal initiation is controlled by MAPK-mediated regulation of the bHLH SPEECHLESS. Science 2008, 322, 1113-1116. [CrossRef]

165. MacAlister, C.A.; Ohashi-lto, K.; Bergmann, D.C. Transcription factor control of asymmetric cell divisions that establish the stomatal lineage. Nature 2007, 445, 537-540. [CrossRef] [PubMed]

166. Krysan, P.J.; Jester, P.J.; Gottwald, J.R.; Sussman, M.R. An Arabidopsis mitogen-activated protein kinase kinase kinase gene family encodes essential positive regulators of cytokinesis. Plant Cell 2002, 14, 1109-1120. [CrossRef]

167. Beck, M.; Komis, G.; Ziemann, A.; Menzel, D.; Šamaj, J. Mitogen-activated protein kinase 4 is involved in the regulation of mitotic and cytokinetic microtubule transitions in Arabidopsis thaliana. New Phytol. 2011, 189, 1069-1083. [CrossRef]

168. Li, K.; Yang, F.B.; Zhang, G.Z.; Song, S.F.; Li, Y.; Ren, D.T.; Miao, Y.C.; Song, C.P. AIK1, A mitogen-activated protein kinase, modulates abscisic acid responses through the MKK5-MPK6 kinase cascade. Plant Physiol. 2017, 173, 1391-1408. [CrossRef]

169. Stahl, Y.; Wink, R.H.; Ingram, G.C.; Simon, R. A signaling module controlling the stem cell niche in Arabidopsis root meristems. Curr. Biol. 2009, 19, 909-914. [CrossRef]

170. Wang, L.; Yang, T.; Wang, B.Q.; Lin, Q.L.; Zhu, S.R.; Li, C.Y.; Ma, Y.C.; Tang, J.; Xing, J.J.; Li, X.S.; et al. RALF1-FERONIA complex affects splicing dynamics to modulate stress responses and growth in plants. Sci. Adv. 2020, 6, eaaz1622. [CrossRef]

171. Haruta, M.; Sabat, G.; Stecker, K.; Minkoff, B.B.; Sussman, M.R. A peptide hormone and its receptor protein kinase regulate plant cell expansion. Science 2014, 343, 408-411. [CrossRef] [PubMed]

172. Xun, Q.Q.; Wu, Y.Z.; Li, H.; Chang, J.K.; Ou, Y.; He, K.; Gou, X.P.; Tax, F.E.; Li, J. Two receptor-like protein kinases, MUSTACHES and MUSTACHES-LIKE, regulate lateral root development in Arabidopsis thaliana. New Phytol. 2020, 227, 1157-1173. [CrossRef] [PubMed]

173. Matsuzaki, Y.; Ogawa-Ohnishi, M.; Mori, A.; Matsubayashi, Y. Secreted peptide signals required for maintenance of root stem cell niche in Arabidopsis. Science 2010, 329, 1065-1067. [CrossRef]

174. Shinohara, H.; Mori, A.; Yasue, N.; Sumida, K.; Matsubayashi, Y. Identification of three LRR-RKs involved in perception of root meristem growth factor in Arabidopsis. Proc. Natl. Acad. Sci. USA 2016, 113, 3897-3902. [CrossRef]

175. An, Z.; Liu, Y.; Ou, Y.; Li, J.; Zhang, B.; Sun, D.; Sun, Y.; Tang, W. Regulation of the stability of RGF1 receptor by the ubiquitin-specific proteases UBP12/UBP13 is critical for root meristem maintenance. Proc. Natl. Acad. Sci. USA 2018, 115, 1123-1128. [CrossRef]

176. Lu, X.; Shi, H.; Ou, Y.; Cui, Y.; Chang, J.; Peng, L.; Gou, X.; He, K.; Li, J. RGF1-RGI1, a peptide-receptor complex, regulates Arabidopsis root meristem development via a MAPK signaling cascade. Mol. Plant 2020. [CrossRef]

177. Shao, Y.; Yu, X.; Xu, X.; Li, Y.; Yuan, W.; Xu, Y.; Mao, C.; Zhang, S.; Xu, J. The YDA-MKK4/MKK5-MPK3/MPK6 cascade functions downstream of the RGF1-RGI ligand-receptor pair in regulating mitotic activity in the root apical meristem. Mol. Plant 2020. [CrossRef]

178. Aida, M.; Beis, D.; Heidstra, R.; Willemsen, V.; Blilou, I.; Galinha, C.; Nussaume, L.; Noh, Y.S.; Amasino, R.; Scheres, B. The PLETHORA genes mediate patterning of the Arabidopsis root stem cell niche. Cell 2004, 119, 109-120. [CrossRef]

179. Fernandez, A.; Drozdzecki, A.; Hoogewijs, K.; Vassileva, V.; Madder, A.; Beeckman, T.; Hilson, P. The GLV6/RGF8/CLEL2 peptide regulates early pericycle divisions during lateral root initiation. J. Exp. Bot. 2015, 66, 5245-5256. [CrossRef] [PubMed]

180. Fernandez, A.I.; Vangheluwe, N.; Xu, K.; Jourquin, J.; Claus, L.A.N.; Morales-Herrera, S.; Parizot, B.; De Gernier, H.; Yu, Q.Z.; Drozdzecki, A.; et al. GOLVEN peptide signalling through RGI receptors and MPK6 restricts asymmetric cell division during lateral root initiation. Nat. Plants 2020, 6, 533-543. [CrossRef] [PubMed]

181. Cao, M.; Chen, R.; Li, P.; Yu, Y.; Zheng, R.; Ge, D.; Zheng, W.; Wang, X.; Gu, Y.; Gelova, Z.; et al. TMK1-mediated auxin signalling regulates differential growth of the apical hook. Nature 2019, 568, 240-243. [CrossRef] [PubMed] 
182. Huang, R.; Zheng, R.; He, J.; Zhou, Z.; Wang, J.; Xiong, Y.; Xu, T. Noncanonical auxin signaling regulates cell division pattern during lateral root development. Proc. Natl. Acad. Sci. USA 2019, 116, 21285-21290. [CrossRef] [PubMed]

183. Kumpf, R.P.; Shi, C.L.; Larrieu, A.; Sto, I.M.; Butenko, M.A.; Peret, B.; Riiser, E.S.; Bennett, M.J.; Aalen, R.B. Floral organ abscission peptide IDA and its HAE/HSL2 receptors control cell separation during lateral root emergence. Proc. Natl. Acad. Sci. USA 2013, 110, 5235-5240. [CrossRef] [PubMed]

184. Brand, U.; Fletcher, J.C.; Hobe, M.; Meyerowitz, E.M.; Simon, R. Dependence of stem cell fate in Arabidopsis on a feedback loop regulated by CLV3 activity. Science 2000, 289, 617-619. [CrossRef] [PubMed]

185. Schoof, H.; Lenhard, M.; Haecker, A.; Mayer, K.F.; Jurgens, G.; Laux, T. The stem cell population of Arabidopsis shoot meristems is maintained by a regulatory loop between the CLAVATA and WUSCHEL genes. Cell 2000, 100, 635-644. [CrossRef]

186. Hu, C.; Zhu, Y.F.; Cui, Y.W.; Cheng, K.L.; Liang, W.; Wei, Z.Y.; Zhu, M.S.; Yin, H.J.; Zeng, L.; Xiao, Y.; et al. A group of receptor kinases are essential for CLAVATA signalling to maintain stem cell homeostasis. Nat. Plants 2018, 4, 205-211. [CrossRef]

187. Betsuyaku, S.; Takahashi, F.; Kinoshita, A.; Miwa, H.; Shinozaki, K.; Fukuda, H.; Sawa, S. Mitogen-activated protein kinase regulated by the CLAVATA receptors contributes to shoot apical meristem homeostasis. Plant Cell Physiol. 2011, 52, 14-29. [CrossRef]

188. Duan, P.G.; Rao, Y.C.; Zeng, D.L.; Yang, Y.L.; Xu, R.; Zhang, B.L.; Dong, G.J.; Qian, Q.; Li, Y.H. SMALL GRAIN 1, which encodes a mitogen-activated protein kinase kinase 4, influences grain size in rice. Plant J. 2014, 77, 547-557. [CrossRef]

189. Xu, R.; Duan, P.; Yu, H.; Zhou, Z.; Zhang, B.; Wang, R.; Li, J.; Zhang, G.; Zhuang, S.; Lyu, J.; et al. Control of grain size and weight by the OsMKKK10-OsMKK4-OsMAPK6 signaling pathway in Rice. Mol. Plant 2018, 11, 860-873. [CrossRef]

190. Guo, T.; Lu, Z.Q.; Shan, J.X.; Ye, W.W.; Dong, N.Q.; Lin, H.X. ERECTA1 acts upstream of the OsMKKK10-OsMKK4-OsMPK6 cascade to control spikelet number by regulating cytokinin metabolism in rice. Plant Cell 2020. [CrossRef]

191. Xu, J.; Zhang, S. Mitogen-activated protein kinase cascades in signaling plant growth and development. Trends Plant Sci. 2015, 20, 56-64. [CrossRef]

192. Rodriguez, M.C.; Petersen, M.; Mundy, J. Mitogen-activated protein kinase signaling in plants. Annu. Rev. Plant Biol. 2010, 61, 621-649. [CrossRef]

193. Stanko, V.; Giuliani, C.; Retzer, K.; Djamei, A.; Wahl, V.; Wurzinger, B.; Wilson, C.; Heberle-Bors, E.; Teige, M.; Kragler, F. Timing is everything: Highly specific and transient expression of a MAP kinase determines auxin-induced leaf venation patterns in Arabidopsis. Mol. Plant 2014, 7, 1637-1652. [CrossRef] [PubMed]

194. Forde, B.G.; Cutler, S.R.; Zaman, N.; Krysan, P.J. Glutamate signalling via a MEKK1 kinase-dependent pathway induces changes in Arabidopsis root architecture. Plant J. 2013, 75, 1-10. [CrossRef]

195. Escobar-Restrepo, J.M.; Huck, N.; Kessler, S.; Gagliardini, V.; Gheyselinck, J.; Yang, W.C.; Grossniklaus, U. The FERONIA receptor-like kinase mediates male-female interactions during pollen tube reception. Science 2007, 317, 656-660. [CrossRef] [PubMed]

196. Boisson-Dernier, A.; Roy, S.; Kritsas, K.; Grobei, M.A.; Jaciubek, M.; Schroeder, J.I.; Grossniklaus, U. Disruption of the pollen-expressed FERONIA homologs ANXUR1 and ANXUR2 triggers pollen tube discharge. Development 2009, 136, 3279-3288. [CrossRef] [PubMed]

197. Miyazaki, S.; Murata, T.; Sakurai-Ozato, N.; Kubo, M.; Demura, T.; Fukuda, H.; Hasebe, M. ANXUR1 and 2, sister genes to FERONIA/SIRENE, are male factors for coordinated fertilization. Curr. Biol. 2009, 19, 1327-1331. [CrossRef]

198. Wang, T.; Liang, L.; Xue, Y.; Jia, P.F.; Chen, W.; Zhang, M.X.; Wang, Y.C.; Li, H.J.; Yang, W.C. A receptor heteromer mediates the male perception of female attractants in plants. Nature 2016, 531, 241-244. [CrossRef] [PubMed]

199. Okuda, S.; Tsutsui, H.; Shiina, K.; Sprunck, S.; Takeuchi, H.; Yui, R.; Kasahara, R.D.; Hamamura, Y.; Mizukami, A.; Susaki, D.; et al. Defensin-like polypeptide LUREs are pollen tube attractants secreted from synergid cells. Nature 2009, 458, 357-361. [CrossRef]

200. Takeuchi, H.; Higashiyama, T. Tip-localized receptors control pollen tube growth and LURE sensing in Arabidopsis. Nature 2016, 531, 245-248. [CrossRef] 
201. Kim, T.W.; Wang, Z.Y. Brassinosteroid signal transduction from receptor kinases to transcription factors. Annu. Rev. Plant Biol. 2010, 61, 681-704. [CrossRef]

202. Matsuoka, D.; Furuya, T.; Iwasaki, T.; Nanmori, T. Identification of tyrosine autophosphorylation sites of Arabidopsis MEKK1 and their involvement in the regulation of kinase activity. FEBS Lett. 2018, 592, 3327-3334. [CrossRef] [PubMed]

203. Kong, Q.; Qu, N.; Gao, M.; Zhang, Z.; Ding, X.; Yang, F.; Li, Y.; Dong, O.X.; Chen, S.; Li, X.; et al. The MEKK1-MKK1/MKK2-MPK4 kinase cascade negatively regulates immunity mediated by a mitogen-activated protein kinase kinase kinase in Arabidopsis. Plant Cell 2012, 24, 2225-2236. [CrossRef]

204. Qiu, J.L.; Zhou, L.; Yun, B.W.; Nielsen, H.B.; Fiil, B.K.; Petersen, K.; Mackinlay, J.; Loake, G.J.; Mundy, J.; Morris, P.C. Arabidopsis mitogen-activated protein kinase kinases MKK1 and MKK2 have overlapping functions in defense signaling mediated by MEKK1, MPK4, and MKS1. Plant Physiol. 2008, 148, $212-222$. [CrossRef] [PubMed]

205. Shakeel, S.N.; Gao, Z.; Amir, M.; Chen, Y.F.; Rai, M.I.; Haq, N.U.; Schaller, G.E. Ethylene regulates levels of ethylene receptor/CTR1 signaling complexes in Arabidopsis thaliana. J. Biol. Chem. 2015, 290, 12415-12424. [CrossRef]

206. Clark, K.L.; Larsen, P.B.; Wang, X.; Chang, C. Association of the Arabidopsis CTR1 Raf-like kinase with the ETR1 and ERS ethylene receptors. Proc. Natl. Acad. Sci. USA 1998, 95, 5401-5406. [CrossRef] [PubMed]

207. Kieber, J.J.; Rothenberg, M.; Roman, G.; Feldmann, K.A.; Ecker, J.R. CTR1, a negative regulator of the ethylene response pathway in Arabidopsis, encodes a member of the raf family of protein kinases. Cell 1993, 72, 427-441. [CrossRef]

208. Ouaked, F.; Rozhon, W.; Lecourieux, D.; Hirt, H. A MAPK pathway mediates ethylene signaling in plants. EMBO J. 2003, 22, 1282-1288. [CrossRef]

209. Liang, X.; Zhou, J.M. Receptor-like cytoplasmic kinases: Central players in plant receptor kinase-mediated signaling. Annu. Rev. Plant Biol. 2018, 69, 267-299. [CrossRef]

210. Burr, C.A.; Leslie, M.E.; Orlowski, S.K.; Chen, I.; Wright, C.E.; Daniels, M.J.; Liljegren, S.J. CAST AWAY, a membrane-associated receptor-like kinase, inhibits organ abscission in Arabidopsis. Plant Physiol. 2011, 156, 1837-1850. [CrossRef]

211. Du, C.; Li, X.; Chen, J.; Chen, W.; Li, B.; Li, C.; Wang, L.; Li, J.; Zhao, X.; Lin, J.; et al. Receptor kinase complex transmits RALF peptide signal to inhibit root growth in Arabidopsis. Proc. Natl. Acad. Sci. USA 2016, 113, E8326-E8334. [CrossRef]

212. Liu, J.J.; Zhong, S.; Guo, X.Y.; Hao, L.H.; Wei, X.L.; Huang, Q.P.; Hou, Y.N.; Shi, J.; Wang, C.Y.; Gu, H.Y.; et al. Membrane-bound RLCKs LIP1 and LIP2 are essential male factors controlling male-female attraction in Arabidopsis. Curr. Biol. 2013, 23, 993-998. [CrossRef]

213. Kakita, M.; Murase, K.; Iwano, M.; Matsumoto, T.; Watanabe, M.; Shiba, H.; Isogai, A.; Takayama, S. Two distinct forms of $M$-locus protein kinase localize to the plasma membrane and interact directly with $S$-locus receptor kinase to transduce self-incompatibility signaling in Brassica rapa. Plant Cell 2007, 19, 3961-3973. [CrossRef]

214. Murase, K.; Shiba, H.; Iwano, M.; Che, F.S.; Watanabe, M.; Isogai, A.; Takayama, S. A membrane-anchored protein kinase involved in Brassica self-incompatibility signaling. Science 2004, 303, 1516-1519. [CrossRef] [PubMed]

Publisher's Note: MDPI stays neutral with regard to jurisdictional claims in published maps and institutional affiliations.

(C) 2020 by the authors. Licensee MDPI, Basel, Switzerland. This article is an open access article distributed under the terms and conditions of the Creative Commons Attribution (CC BY) license (http://creativecommons.org/licenses/by/4.0/). 